\title{
Religion as a Self-Referential System of Religious Communication: An Assessment with Questions for a Challenging New Theological System. Notes of a Preliminary and (Merely) Intuitive Approach
}

\author{
Fábio Henrique Abreu ${ }^{1}$
}

\begin{abstract}
The following considerations do not properly configure an academic article, but rather intend to offer a critical reaction to the lecture given by Prof. Dr. habil. Christian Danz, from the University of Vienna, on the occasion of the "25th Seminar in Dialogue with the Thought of Paul Tillich" - held under the title "Religion, Language, and Culture: Relevance and Limits of Paul Tillich's Theology of Culture for the 21st Century," between September 15th and 22nd, 2021. Danz's lecture, entitled "Theology, Religion, Culture. Reflections on the Task of Systematic Theology following Paul Tillich," brings not only an exegetical exposition of Tillich's theology of culture, but also a sturdy criticism regarding the foundation of his concept of religion in the face of the religious pluralism of modern democratic societies. The thesis presented by Danz can be summarized in three points: 1) the transcendental foundation of Tillich's concept of religion makes his theology incapable of dealing with religious pluralism; 2) given that the academic concept of religion is a product of neoProtestantism, the concept of religion must be restricted to the Christian religion; 3) finally, the function of the concept of religion within the theological system lies in
\end{abstract}

\footnotetext{
${ }^{1} \mathrm{PhD}$ in Science of Religion - Federal University of Juiz de Fora. Post-doctorate in Philosophy of Religion - Federal University of Juiz de Fora/Evangelisch-Theologische Fakultät der Universität Wien. Currently developing habilitation research in Systematic Theology at the Evangelisch-Theologische Fakultät der Universität Wien under the supervision of Prof. Dr. habil. Christian Danz. I would like to record my gratitude to my dear friend Diana Dee Toups for all her help and encouragement.
} 
its ability to conceptually apprehend and determine Christianity as a religion. Based on the critique of the foundation of the concept of religion developed by Tillich, Danz proposes a new concept of religion in the perspective of a "self-referential system of religious communication." Constitutive to the self-referential system of religious communication is the concept of "verstehende Aneignung," or "understanding appropriation," which, in turn, can only occur within the system of religious communication. The text that follows is an attempt, and while still incipient and intuitive, it offers a rather "suspicious" approach to the theological system proposed by Danz. The first part is intended for a comprehensive synthesis of the substantive content of the lecture given. The second part presents initial considerations and questions regarding the foundations of the proposed new theological system. Keywords: Paul Tillich; theology of culture; concept of religion; religious pluralism; Christian Danz; selfreferential system; religious communication; verstehende Aneignung.

Religião como um sistema autorreferencial de comunicação religiosa: uma avaliação com perguntas para um desafiante e novo sistema teológico. Notas de uma abordagem preliminar e (meramente) intuitiva

\section{RESUMO}

As considerações a seguir não configuram propriamente um artigo acadêmico, mas intencionam, antes, oferecer uma reação crítica à palestra proferida pelo Prof. Dr. habil. Christian Danz, da Universidade de Viena, no âmbito do " $25^{\circ}$ Seminário em Diálogo com o Pensamento de Paul Tillich" - realizado sob o título "Religião, linguagem e cultura: relevância e limites da teologia da cultura de Paul Tillich para o século XXI", entre os dias 15 e 22 de setembro de 2021. A palestra de Danz, intitulada "Theology, Religion, Culture. Reflections on the Task of Systematic Theology following Paul Tillich", traz não apenas uma exposição exegética da teologia da cultura de Tillich, como também críticas intensas no que diz respeito à fundamentação de seu conceito de religião em face do pluralismo religioso das sociedades democráticas 
modernas. A tese apresentada por Danz pode ser resumida em três pontos: 1) a fundamentação transcendental do conceito de religião de Tillich torna sua teologia incapaz de lidar com o pluralismo religioso; 2) tendo-se em vista que o conceito acadêmico de religião é um produto do "neoprotestantismo", o conceito de religião deve ser restrito à religião cristã; 3) por fim, a função do conceito de religião dentro do sistema teológico reside em sua capacidade de apreender conceitualmente e determinar o cristianismo como religião. Com base na crítica à fundamentação do conceito de religião desenvolvido por Tillich, Danz propõe um novo conceito de religião sob o prisma de um "sistema autorreferencial de comunicação religiosa". Constitutivo para o sistema autorreferencial de comunicação religiosa é o conceito de "verstehende Aneignung", ou "apropriação compreensiva", que, por sua vez, somente pode ocorrer dentro do sistema de comunicação religiosa. O texto que se segue é uma tentativa, ainda incipiente e intuitiva, de oferecer uma aproximação "em suspeição" no que diz respeito ao sistema teológico proposto por Danz. A primeira parte é destinada à uma síntese compreensiva do conteúdo substantivo da palestra proferida. Na segunda parte de minha exposição, teço considerações iniciais e questionamentos em relação aos fundamentos do novo sistema teológico proposto.

Palavras-chave: Paul Tillich; teologia da cultura; conceito de religião; pluralismo religioso; Christian Danz; sistema autorreferencial; comunicação religiosa; verstehende Aneignung.

"No one is universal outside their backyards" (Vinícius de Moraes, 1913-1980).

„Ja sie selbst, die Theologie, ist nur insofern noch productiv, als sie destructiv ist. Ihr Beruf in jetziger Zeit besteht darin (und zwar heisst es auch hier: fata volentem ducunt, nolentem trahunt), ein Gebäude, das in den Bauplan der neuen Welt nicht mehr passt, in der Art abzutragen, dass es den Bewohnern nicht geradezu über den Kopf geworfen, sondern ihr 
allmähliger Auszug theils abgewartet, theils aber doch beschleunigt werde“. ${ }^{2}$

\section{Synthesis of Prof. Dr. Danz's Lecture: “Theology, Religion, Culture. Reflections on the Task of Systematic Theology following Paul Tillich"}

Dear Prof. Dr. habil. Christian Danz, thank you very much for your wonderful lecture and for taking on the difficult task of "planned theological destruction," which prevented the building from collapsing on our heads. More than that, from this meticulous task of deconstruction and destruction, it is possible to see that, under the rubble, a new foundation is laid. Like someone who, feeling without a roof, still looks at an open horizon without knowing exactly the final shape of the planned building - after all, I have contemplated only a part of the construction plan so far! -, I am going to try to make some brief observations on the fundamental aspects you have pointed out in your presentation and raise some questions at the end regarding the edifice build plan - for, after all, I am curious.

Leaving the language of civil construction aside, I am going to focus, in what follows, on the criticisms of Tillich's theology of culture - its reasons advanced by you, leaving the description of the structure of his Kulturtheologie aside. My intention is to try to unravel, based on the criticisms you directed against Tillich's system, the image of the theological-systematic edifice that you are proposing as an alternative. It is from this image, so far only partial, that I am going to raise some questions at the end of this exposition in order to better understand the project of a theology as a self-referential system of religious communication as proposed by you in your lecture and elsewhere. In all likelihood, it is possible that I am going to find out much more about the place where I stand and from where I observe than about your system itself. However, I think this exercise is not only a healthy one, but also highly necessary. Without knowing the place where we are in detail, it becomes virtually impossible to appreciate new landscapes, new horizons, new perspectives - and that is precisely what I intend to do, even so that the place where I am is not invaded

\footnotetext{
${ }^{2}$ STRAUSS, D. F. Die christliche Glaubenslehre in ihrer geschichtlichen Entwicklung und im Kampfe mit der modernen Wissenschaft dargestellt. Zweiter Band. Tübingen: C. F. Osiander; Stuttgart: F. H. Köhler, 1841, p. 624: "Indeed, theology itself is still productive only insofar as it is destructive. Its vocation today is (and here, in fact, it is said: fata volentem ducunt, nolentem trahunt) to demolish a building that is no longer based on the construction plan of the new world, but to prevent it from falling on the heads of its inhabitants, this task must be carried out carefully, little by little, and yet without wasting time." The Latin sentence, attributed to Lucius Annaeus Seneca, a famous intellectual of the Roman Empire, can be literally translated as follows: "destiny guides those who obey it and drags with it those who oppose it." [All translations are my own $=$ FHA.]
} 
by the tedious power of monotony and the habitus of endless irreflexive repetition. ${ }^{3}$

I must start by recognizing that the substantive content of your lecture is extremely concise and difficult to delineate. Nonetheless, the overall intention of your presentation is rather clear. It concerns, as you openly and programmatically state, a new systematic foundation for a theology of culture in the twenty-first century. By a new systematic foundation for a theology of culture, I do not mean here to imply a simple break with the modern Protestant theological tradition - to which Tillich's program remains extremely indebted while renewing it from new theoretical bases. What I mean by a new foundation for a theology of culture, which in itself demands a new foundation for the whole theological system as such, ${ }^{4}$ is that, based on an encyclopedic knowledge of the philosophical tradition of enlightened modernity - above all, from the Kantian inflection in philosophy, as well as from the development of the modern Protestant theological tradition since Schleiermacher -, you propose a new theological system that can only be understood, in my judgment, as a rupture in dependence, i.e., a rupture that imposes itself in the form of a continuity with, and renewal of, the modern intellectual tradition with which your systematic program breaks. This programmatic intention makes your new theologicalsystematic program all the more commendable insofar as it is concerned with taking seriously one of the main - if not the main - characteristics of modern societies, namely, the intense pluralization of all spheres of life, including, of course, that of religion. ${ }^{5}$ And, here, all the theoretical difficulties and reservations arise, for your program calls into question the fundamental starting point of a theological tradition that, despite its polychromatic character, still demarcates the contemporary theological agenda, especially in the Germanspeaking Protestant academic scenario - namely, the liberal theological tradition. "But," as Hölderlin said, "where the danger lies, also grows the saving

\footnotetext{
${ }^{3}$ Cf. MEDEIROS, M. A morte devagar. In: Non-Stop. Crônicas do cotidiano. Porto Alegre: L\&PM Editores, 2001, p. 145: "Morre lentamente quem vira escravo do hábito, repetindo todos os dias o mesmo trajeto e as mesmas compras no supermercado. Quem não troca de marca, não arrisca vestir uma cor nova, não dá papo para quem não conhece". I venture a translation here: "He who become slaves of habit, repeating the same route and shopping at the supermarket every day; who does not change brands, does not risk and change the color of his clothes, who does not talk to those whom does not know, dies slowly."

${ }^{4}$ This task of a new foundation of the theological system is presented by you in your book on the systemic-theoretical function of the doctrine of the Holy Spirit. Here, cf. DANZ, C. Gottes Geist. Eine Pneumatologie. Tübingen: Mohr Siebeck, 2019, above all, p. 101-194.

${ }^{5}$ Cf., for instance, BERGER, P. L. The Sacred Canopy: Elements of a Sociological Theory of Religion. New York: Anchor Books, 1990, p. 138; cf. also BERGER, P. L.; LUCKMANN, T. Modernity, Pluralism and the Crisis of Meaning: The Orientation of Modern Man. Gütersloh: Bertelsmann Foundation Publishers, 1995.
} 
power [Wo aber Gefahr ist, wächst das Rettende auch]." ${ }^{\prime 6}$ In this sense, in contrast to those theologians who may take your new system in consideration under the key of "danger and threat," I understand it as an opportunity and an invitation for us to rethink, with all the intellectual honesty that is imposed on us, and under the prism of a new critical perspective -, and, more accurately, "systemic-theoretical" (here, with special reference to Niklas Luhmann's theory of systems) -, precisely those bases that we considered and still consider the safest and most critical for the foundation of the theory of religion and the theological system under the "conditions of possibility" of modernity. In this sense, together with the threat that always necessarily seems to accompany that which is new, I manage to contemplate, at the same time, a saving power that, hopefully, will help us to resume the modern task of interiorization of the Religionskritik as the starting point for the foundation and justification of the theological system and of the modern theory of religion. ${ }^{7}$

You start your presentation with a brief description of the structure of Tillich's theology of culture. Although it is very brief and concise on the one hand, it is extremely precise on the other. This already shows your remarkable power of synthesis. The structure of Tillich's theology of culture can only be grasped by those of us who are familiar with its foundational concepts and the historical development of his thinking. Even so, your presentation was able to synthesize it in a way that was very conducive to our interests.

Despite the relevance of Tillich's thinking, his concept of religion is, according to the main thesis advanced in your lecture, "in need of revision." There are at least three aspects that must be criticized and reconstructed in a highly different manner. Given that religion is determined by Tillich as directedness towards the unconditioned, or, "das, was uns unbedingt angeht," as the later formula reads, its universality is already presupposed. The determination of a universal concept of religion is the first point that must be reevaluated. Whenever religion happens, it happens always as an event of selfreflexivity that brings the self-disclosedness of consciousness to its inner transparency and historicity. In this manner, however different and plural they might be, every religion finds its foundation in the same dimension of unconditionality of consciousness. Religious differences are restricted, therefore, to their symbolic self-interpretations. They are different only in so far they make use of different symbolic expressions. Religious symbols, in turn, are

\footnotetext{
${ }^{6}$ HÖLDERLIN, F. Patmos. (1803). In: SCHWAB, C. T. (Hg.). Sämmtliche Werke. Zweiter Band: Nachlaß und Biographie. Stuttgart; Tübingen: J. G. Cotta'scher Verlag, 1846, p. 222-228, here, p. 222.

7 On the programmatic and methodic interconnection between the critique of religion (Religionskritik) and the justification of religion (Religionsbegründung), cf. SCHÜTTE, H.-W. Religionskritik und Religionsbegründung. In: SCHIFFERS, N.; SCHÜTTE, H.-W. (Hg.). Zur Theorie der Religion. Freiburg; Basel; Wien: Herder Verlarg, 1973, p. 95-135; WAGNER, F. Was is Religion? Studien zu ihrem Begriff und Thema in Geschichte und Gegenwart. Gütersloh: Gütersloher Verlagshaus Gerd Mohn, 1986, p. 555-589.
} 
means by which consciousness grasps and presents its self-disclosedness and unconditionality in its inner historicity and reflexivity. In other words, the same foundational structure, namely, the unconditioned, underlies every particular religion. In this sense, the plurality of religious phenomena seems to be evaded only in so far as its unverifiable common ground is presupposed. The inner core that remains is, however, the same. Only the shell, i.e., the historical actualization of religious phenomena, changes.

The second difficulty stemming from Tillich's determination of the concept of religion on the basis of the self-relatedness of the spirit, i.e., the unconditionality of self-relation (Unbedingtheit im Selbstverhältnis), lies within the fact that religion functions here as the unity of the self-differentiated modern culture. The systemic self-differentiation process of modern culture into different subsystems ${ }^{8}$ is, so to say, overcome by means of an appeal to the unconditioned ground of "reality" as the unity of the whole culture. Tillich conceives of religion as an event of self-reflexivity that takes place in the spirit, and consequently, in the meaning functions of the spirit. This event dissolves the notion of religion as a particular form of meaning alongside others. By means of this determination of the concept of religion as an event of selfreflexivity that happens in the cultural functions of consciousness, Tillich is able to establish a new, theonomous culture that seems to gloss over the differences of autonomous religious systems as cultural forms on their own. Given that the unconditioned cannot be determined without being at the same time negated in its very unconditionality, it follows that the autonomous determinacy of religions as autonomous forms of meaning must be negated in their conditionality and concrete determinacy. The double negation intrinsic to the concept of the unconditioned is thus programmatic. It aims to assume the autonomous forms of culture only in so far they are negated in their very autonomous self-determinations. The unity of culture is, as a result, secured. Nonetheless, it has its prices, for the unity of culture lies precisely in the negation of its particularity and autonomy. As you stated, "such a model of unity that grounds Tillich's theology of culture, and the claim connected with which that aims to give a new justification for the unity of the differentiated culture, is under the conditions of present culture and society mere romanticism" (emphasis mine).

The third difficulty has to do with the autonomous self-interpretation and self-presentation of the human being. Bearing in mind that the unconditioned

$8 \mathrm{Cf}$, in this connection, LUHMANN, N. Die Ausdifferenzierung der Religion. In: Gesellschaftsstruktur und Semantik. Studien zur Wissenssoziologie der modernen Gesellschaft. Band 3. Frankfurt am Main: Surhkamp Verlag, 1989, p. 259-357; WAGNER, F. Kann die Religion der Moderne die Moderne der Religion ertragen? Religionssoziologische und theologisch-philosophische Erwägungen im Anschlus an Niklas Luhmann. In: DANZ, C.; DIERKEN, J.; MURRMANN-KAHL, M. (Hg.). Religion zwischen Rechtfertigung und Kritik. Perspektiven philosophischer Theologie. Frankfurt am Main: Peter Lang GmbH; Internationaler Verlag der Wissenschaften, 2005, p. 173-201. 
underlies every consciousness, and that the unconditioned is the foundational basis from which the concept of religion is constructed, a non-religious mode of self-interpretation is always and necessarily a self-interpretation that has not yet become transparent in relation to its unconditional dimension. It is, therefore, a self-interpretation that, despite its autonomous self-determination, remains "deficient." The unconditioned judgment turns against it, i.e., it remains a normative reference that calls into question a non-religious self-interpretation. Insofar as it asserts itself as non-religious, an autonomous self-interpretation seems to be always inferior when compared to a religious symbolic selfinterpretation. A true self-interpretation has to be a religious one because only in religion is the self-disclosedness of the unconditional dimension of consciousness brought to its transparency. Religion is, therefore, the locus of every true self-interpretation and, apart from it, there is no possible selftransparency. The necessary result of these difficulties outlined in your lecture lies upon the fact that Tillich's theology of culture is - ironically! - not able to recognize the pluralism that is intrinsic to modern culture.

In this sense, how are we supposed to assume the task of a theology of culture under the conditions of modern religious pluralism? The first step is, of course, to renounce building any concept of religion that claims to be universal. Against Tillich's insistence upon the claim that religion cannot be conceived of as a particular function of the spirit alongside others, the concept of religion is to be understood "as an autonomous form in culture." Such a determination of the concept of religion consciously places religion precisely where Tillich wants to avoid, for religion is understood in Tillich's theological system as the event in which cultural consciousness becomes graspable, within culture and through the cultural forms, in its depth structure. However, as such, religion is not identical with any cultural form. It is from this point that one can easily see that there are two consequences arising from this construction of the relationship between religion and culture. First, the construction of the concept of religion from the basis of this philosophy of spirit and meaning results in a double concept of religion. From the determination of religion as an event that occurs in the meaning functions of the spirit, Tillich draws a distinction between religion as an event of self-transparency of the spirit and religion as a cultural form. Religion as a cultural form is criticized by Tillich as a form of religion in which awareness of the depth structure of the spirit is emptied. Second, religion, understood as an event in the cultural forms, is, for Tillich, an event that cannot be derived and is therefore always already concrete. In this sense, religion cannot be created. It is not a cultural production, an epiphenomenon, but occurs only as an underivable event in which the self-transparency of the unconditionality dimension of the spirit takes place. In open and conscious contrast to Tillich, however, you claim that "religion is to be assumed as an autonomous form in culture, which has differentiated itself as a separate realm in the process of cultural evolution" (emphasis mine). The necessary result of 
this determination of the concept of religion is that it, religion, is not a necessary constitution of the human being, i.e., it is not a conditio humana, as modern Protestant theology from Schleiermacher to Tillich (and beyond), mutatis mutandis, has assumed, as well as programmatically, systematically advanced.

However, does it mean that the concept of religion as such is scientifically useless? That certainly is not the position advanced in your lecture. ${ }^{9}$ Rather, the concept of religion, as you posited it, must be restricted to Christianity. The function of the concept of religion within the theological system lies in its ability to "conceptually grasp and determine Christianity as religion". As you stated,

By renouncing a general concept of religion, the possibility is created to recognize that other religions understand religion differently than Christianity. Thus, it is not a matter of distinguishing only Christianity as a religion or of understanding it as a true and proper religion, but just the other way around, to include in theology and to acknowledge that what is religion is already differently determined in the different religions. Each religion is a religion sui generis and not merely the historical particularization of a general underlying essence that they allegedly have in common.

The alternative is to conceive of religion, that is, religion understood as a concept that needs to be restricted to Christianity and its conceptual selfinterpretation, as a form of communication. To be sure, religion cannot be understood here as a simple form of communication. Rather, religion is religious communication, that is, a communication which is aware of being a religious form of communication. Religion communicates religion in its contentual communication. The circular character of the human sciences is thus consciously assumed. ${ }^{10}$ Religion does not arise by means of preconditions given

\footnotetext{
${ }^{9}$ It would be appropriate to refer our readers, in this connection, to your text on the concept of religion. On this point, cf. DANZ, C. Was ist Religion? Anmerkungen zu ihrem Verständnis. In: SCHREIBER, G. (Hg.). Interesse am Anderen: Interdisziplinäre Beiträge zum Verhältnis von Religion und Rationalität. Für Heiko Schulz zum 60. Geburtstag. Berlin; Boston: Walter de Gruyter GmbH, 2020, p. 3-17.

${ }^{10}$ The circularity of the Geisteswissenschaften is referred to by Tillich in a very precise manner in the first volume of his American Systematic Theology. Cf. TILLICH, P. Systematic Theology. Vol. I: Reason and Revelation, Being and God. Chicago: The University of Chicago Press, 1951, p. 9. Tillich's understanding of the circularity of the Geisteswissenschaften is not an achievement of his later writings, however. The "hermeneutic circle" advanced, for insistence, in his essay "Cristologie und Geschichtsdeutung," from 1930, already brings this problem into due consideration. In this connection, cf. TILLICH, P. Cristologie und Geschichtsdeutung. (1930). In: HUMMEL, G. (Hg.). Main Works - Hauptwerke. Band 6: Theologische Schriften. Berlin; New York: Walter de Gruyter; Evangelisches Verlagswerk, 1992, p. 127-149. In this work, Tillich says that history is not an objective-empirical process that somehow already exists or would be given regardless of the subject interpreting history. Tillich expressly rejects such a cum grano salis scientific view of history as inadequate. Rather,
} 
outside the religious system of communication, such as attempts which offer a transcendental foundation of the concept of religion claim. As you describe it,

Constitutive for the Christian religion is an interrelation of three structural elements: first, it depends on Christian-religious

history only arises through an act of interpretation. Tillich explains that the concept of history is incomprehensible without a moment of subjectivity. It is true, however, as Tillich says, that a "separation of the objective existence of history and a subjective judgment of its being and nonbeing [...] should definitely be rejected" (p. 194). For, according to Tillich, such a position suggests an objective history for which one can decide subjectively or not. Over against this position, Tillich asserts: "History is posited or cancelled with the decision for or against it, and apart from this positing it has no objective being" (p. 194). Tillich, however, is aware of the dangers of a decisionism in historical matters and immediately turns this circular description of the interpretation of history critical of it: "But - this must be said at the same time and with the same emphasis - this positing is not subjective. It is itself something historical and only possible on the basis of being historically grasped [geschichtlichen Ergriffenseins]" (p. 194). In other words, the interpretation of history is already part of a history that is determined in terms of content and is determined by this very history. This mixture of being determined by a history and the dependence of history on interpretation becomes transparent in faith. That is why, for Tillich, faith is the event in which knowledge of history arises. The historical "hermeneutic circle," which is already laid out in every interpretation of history, must find its expression in dogmatic Christology. This is precisely the systematic content of Tillich's understanding of the biblical image of Christ, as advanced in is Dogmatik-Vorlesungen of 1925-1927. Cf. TILLICH, P. Dogmatik-Vorlesung. (Dresden 1925-1927). In: SCHÜßLER, W.; STURM, E.. (Hg.). Ergänzungs- und Nachlaßbände zu den Gesammelten Werken von Paul Tillich. Band XIV. Berlin; New York: Walter de Gruyter GmbH \& Co., KG, 2005, p. 1-440. Tillich explained his understanding of the biblical image of Christ in his Christological concept of revelation both in the prolegomena of his dogmatics and in the material development of Christology. As a result, Christology not only becomes a philosophy of history, but it also describes the emergence of knowledge about history. „Die Geschichte wird betrachtet als Durchbruch der vollkommenen Offenbarung. Sie ist es aber nur, insofern sie selbst durchbrochen wird. Das, was sie durchbricht, ist ihr sinngebender Grund, das Kommen des Heils“ (p. 329). The constitution of historical consciousness ties Tillich back to the religious act and its self-apprehension. That is why history is constituted, according to Tillich, dogmatically, and not empirically. As Tillich puts it: „Geschichte konstituiert sich also dogmatisch und nur dogmatisch, nur von einem Wechselverhältnis des Geschichte erfassenden Subjekts mit einem die Geschichte schaffenden Objekt, in dem das Subjekt den Ort des Sinnes sieht, der sein Sinn ist, der es, das Subjekt, unbedingt angeht" (p. 372). Tillich had already summarized his Christology-oriented history of religion through his "center of history" formula. On this point, cf. TILLICH, P. DogmatikVorlesung (Dresden 1925-1927), p. 370-373; TILLICH, P. Christologie und Geschichtsdeutung, p. 194-196; TILLICH, P. Systematic Theology. Vol. I: Reason and Revelation, Being and God, p. 132-147. On the formula "center of history", cf. the following studies: WITTEKIND, F. Die Vernunft des Christusglaubens. Zu den philosophischen Hintergründen der Christologie der Marburger Dogmatik. In: DANZ, C.; SCHÜßLER, W.; STURM, E. (Hg.). Internationales Jahrbuch für die Tillich-Forschung. Band 1: Wie viel Vernunft braucht der Glaube? Wien: LIT Verlag, 2005, p. 133-157; DANZ, C. Jesus Christus als Mitte der Geschichte. Die geschichtsphilosophischen Grundlagen von Paul Tillichs Christologie. In: HAIGIS, P.; HUMMEL, G.; LAX, D. (Hg.). Christus Jesus - „Mitte der Geschichte"!? Beiträge des X. Internationalen Paul-Tillich-Symposions Frankfurt/Main 2004. Berlin: LIT Verlag, 2007, p. 142-154. 
communication, i.e., the memory of Jesus Christ, which must already exist in culture; second, Christian religion depends on the understanding appropriation (verstehende Aneignung) of the memory of Jesus Christ; and third, on the symbolic articulation of the appropriated memory of Jesus Christ. As a religion, Christian religion arises alone from all three moments together. It cannot be traced back or justified on one of these elements. Only by people taking up the Christian religious communication as religion and using it for the representation of religion, does the Christian religion exist.

Here it would be important to emphasize that the determination of religion as communication does not result in a purely descriptive task. Rather, religious communication brings with it, at the same time, a normative element: it depends exclusively on the use that people make of the communication. As a self-referential, self-aware, and in itself structured communication event, Christian religion only exists as a closed, self-referential system ${ }^{11}$ of religious communication that makes use of the contents of Christian tradition religiously. Outside of religious communication there is no Christian religion, and that which determines the religious character of communication lies entirely in its use. In the transparent use of the religious memory of Jesus Christ for the communication of religion, Christianity describes its own self-image. It is the task of systematic theology to construct a self-image of the Christian religion from which it, theology, at the same time, distinguishes itself. ${ }^{12}$ Theology

11 The self-referentiality of the theological system is clear, for instance, in Tillich's 1913 Systematische Theologie, even though Tillich is far from a systemic-theoretical approach as developed by Luhmann and appropriated by Christian Danz. In this early sketch of a Systematic Theology, Tillich develops the critique of the system as a constitutive part of the system. Tillich calls this part of systematic theology "reflection," and it reveals the systemic function of the concept of "paradox" that is so central to his systematic-theological sketch. That is to say, a system has a reflexive part, i.e., a necessary moment where its own self-constitution comes to systemic self-reflection. This is the substance of Tillich's interiorization of Kierkegaard's critique of philosophical systems into his own (namely, Tillich's) theological system. Here, cf. TILLICH, P. Systematische Theologie von 1913. In: HUMMEL, G.; LAX, D. (Hg.). Ergänzungs- und Nachlaßbände zu den Gesammelten Werken von Paul Tillich. Band IX: Frühe Werke. Berlin; New York: Walter de Gruyter GmbH \& Co. KG, 1998, p. 273-434, especially, p. 314-317. Another example here is advanced by Moltmann. For instance, Moltmann, with the idea of "open systems," takes up the debate of the 1970s in order to bring theology and natural science into a new conversation. Moltmann's position on this debate remains highly sub-complex and dependent on his own theological intentions as he uses it, namely, the idea of "open systems," to distinguish and contrast open and closed systems. However, as Moltmann himself partially acknowledges in his book on the doctrine of creation, a system can only be open if it is fully self-referential, i.e., closed. On this point, cf. MOLTMANN, J. Gott in der Schöpfung. Ökologische Schöpfungslehre. München: Chr. Kaiser Verlag, 1985, p. 211.

${ }^{12}$ On this point, cf. DANZ, C. Theologie und Religion. Überlegungen zu einer umstrittenen Unterscheidung. In: HEIL, U.; SCHELlENBERG, A. (Hg.). Theologie als Streitkultur. 
assumes the religious use of communication and constructs this very communication as a self-referential, and in itself structured communication event that is aware of itself as religion. The functioning of religious communication and its understanding appropriation symbolizes the contents of religion in its religious use.

The Trinitarian structure of Christian religious communication is clear in the presentation of your system:

The Holy Spirit represents in the Christian religion its lasting dependence on the memory of Jesus Christ, God represents the binding of the Christian religion to the understanding of communication, and Christ represents the necessity of the symbolic representation of the Christian religion. The representational contents of the Christian religion, which exist as religious contents in religion alone, thus do not have a representational function, but a reflexive one. They symbolize in the Christian religion how it functions as religion and is passed down in history - namely, only in such a way that it hangs as religion on the understanding appropriation and articulation of the handed down religious memory of Jesus Christ (emphasis mine).

Thus, it is in the use of religious communication that the contents of Christian religion can be differentiated from other cultural communications. If the contents of religions are used by politics, for instance, they are no longer religious contents in so far as they make use of a determined political system of communication and its code. In this sense, the use of religious communication dissolves the contents of Christian religion as particular cultural contents: it claims them for itself. The task of systematic theology is, accordingly, to describe how Christian religion comes into being together with its contents in Christian religious communication. The way is thus opened for the establishment of a "hermeneutics of differences"13 as the primary concern of any theological-critical reflection. On the other hand, a criterion for the task of the "discrimination of the gods" is also offered. This criterion is the

Wiener Jahrbuch für Theologie. Band 13. Göttingen: Vandenhoeck \& Ruprecht Verlag; University of Vienna Press, 2021, p. 139-154.

${ }^{13}$ Cf. DANZ, C. Christianity and the Encounter of World Religions. Considerations to a Contemporary Theology of Religions. Revista Eletrônica Correlatio, vol. 15, no. 2, 2016, p. 9-26, here, p. 19: "I refer to such a form of the theology of religions as hermeneutics of difference and I think it is more constructive than the previous debate, which is orientated by the tripartite scheme of the theology of religions. The hermeneutics of difference, firstly, makes possible a differentiated idea of highly complex encounters of worlds of religious symbols. Secondly, it reflects every description of religion from a certain point of view. And, finally, it is able not only to grasp religious worlds of symbols analytically and to interpret them, but also to subject them to a normative reflection. Tillich himself sees the normative telos of the history of religion in the religion of the concrete spirit." [Emphasis mine.] Such a normative criterion, however, changes in the new system, as the note 14 below reveals. 
acknowledgment of the differences amongst religions. That is to say, a religious system of communication that does not acknowledge the differences amongst religions is not to be tolerated. ${ }^{14}$

From this description of the Christian religion based on a self-referential system of religious communication, the starting point is established for a theology of culture under the conditions of religious pluralism in democratic societies. A theology of culture for the twenty-first century must abandon a universal concept of religion in order to take seriously not only the plurality of religions phenomena, but also the plural descriptions that Christianity has of itself.

Christianity becomes different in every time and in every cultural context. Its identity consists solely in the reference back to Jesus Christ and the religious use of his memory. To discuss this, that is, to make possible the change in the self-description of the Christian religion and a recognition of plurality, is the task of a systematic theology of culture in the 21 st century.

At the same time, the theological problem of religious plurality is assumed not only by an ingenious restriction of the concept of religion to the Christian theological tradition, but also by the realization that different forms of religious expression cannot and should not be simply subsumed through the prism of an all-encompassing religious-philosophical and theological concept. For a universal and all-encompassing religious concept reduces the undeniable and irreconcilable differences between religions through the theoretical appeal to an unverifiable foundational dimension that they all supposedly have in common. In this sense, the program, although just outlined in your lecture, but which finds an exhaustive systematic treatment in your Pneumatologie, presents

${ }^{14}$ Cf. DANZ, C. Christianity and the Encounter of World Religions. Considerations to a Contemporary Theology of Religions, p. 19. In a period that we could describe as one of transition in your theological-systematic thinking, the yardstick did not lie in the use of religious communication only, but rather in the normativity of the "finite freedom." As you say in this period: "Theology does not only serve to describe the religious act. Its task is also that of a normative determination of the essence of Christianity. This also is not simply present as a welldefined object, but exists only as a historically bound and mutable self-description. Thus, a normative judgment of the religious life-world of modernity can take place neither by recourse to revealed scripture nor by recourse to a universal religious concept of reason. The historical development of modernity has dissolved both of these. Only the reflexive self-transparency of that act, in which the subject emerges simultaneously with its contents, can function as a criterion. Religious traditions have to be measured against the self-awareness of finite freedom as finite freedom." Cf. DANZ, C. Christianity and the Encounter of World Religions. Considerations to a Contemporary Theology of Religions, p. 23 (Thesis 6: The criterion for judging religious pluralism lies in the reflexive self-transparency of the religious performance). However, the yardstick offered by finite freedom no longer operates, in your new system, as a regulative element for the criticism of religion. Rather, the yardstick lies now in the use of religious communication and in its use alone. 
itself as a theology informed by the facticity of religious plurality, and which is restricted to the theoretical presentation of Christianity from a systemictheoretical construction of the concept of religion as a form of religious communication capable of guaranteeing, at the same time, the particularity of the Christian religion in the midst of the religious plurality of our era.

\section{Critical Reaction and Questions - or, on the Methodological Foundation of a Self-Referential System of Religious Communication}

In what follows, I would like to raise a few questions that, at least to me, seem not only necessary, but imperative, so that the substantive content of your brief and extremely thought-provoking lecture becomes clearer for both myself and our readers. My questions are interconnected and concern the structuring place that the concept of living experience (Erlebnis), and more properly, of religious experience (religiösen Erfahrung), must occupy in any modern theological system. This obviously is a consequence of my liberal theological training, and here I cannot fail to point out my dependence on the legacy of the liberal theological tradition in its determination of the concept of religion on the basis of a "theory of religious experience." 15 It seems to me that, even if you stated the opposite, the concept of religious experience still plays a role in your system - even if it can only be thematized within the system of religious communication and not outside it. However, insofar as you make use of the concept of understanding appropriation (verstehende Aneignung) as a structuring moment of Christian religion, I wonder to what extent this concept is not, in your system, replacing a more general concept of religious experience as the founding moment of all and any religion. Yet, in order to avoid the risk of irresponsibility of issuing hasty and purely external judgments, I must warn you that my questions are presented - in order to make room for Kantian concepts - more in the realm of intuitions than properly in the realm of concepts. Insofar as I am still attempting to correctly understand the fundamental contours of your system, I do not wish to make purely external criticisms, which, as such, are already unqualified criticisms precisely by their exteriority. For all intents and purposes, therefore, I keep Adorno's warning in mind regarding the dangers of a mere "appreciation" of a system of thought. As Adorno rightly said in his Drei Studien zu Hegel, appreciative analyses run the risk of adopting the posture of arrogant judges who pretend to be above something just because they are not in it. In his words,

All appreciations [Würdigungen] fall under the verdict from the preface to the Phenomenology of Spirit, which is passed on those who are above things only because they are not in the things.

${ }^{15}$ LAUSTER, J. Liberale Theologie: Eine Ermunterung. Neue Zeitschrift für Systematische Theologie und Religionsphilosophie, 49, 3, 2008, p. 291-307, here, p. 294-297, p. 301. 


\begin{abstract}
Appreciations miss from the start the seriousness and cogency of Hegel's philosophy by pursuing what he correctly and disparagingly called philosophy of standpoint or perspectives [Standpunktphilosophie]. If one does not want to bounce off him with one's very first word, one must confront, no matter how inadequate, the claim his philosophy makes to truth, instead of just discussing it merely from above, and thereby from below. ${ }^{16}$
\end{abstract}

Having made these preliminary remarks, and explained the place from where I speak, allow me to raise a few questions.

1. My first question concerns what seems to be the starting point of your systematic-theological program, namely, the strict separation between theology and religion. Here you follow not only the process of systemic selfdifferentiation of modern culture into different subsystems, but also the reformulation of the system of sciences (Wissenschaftssystem) in modernity. This process of reformulation of the Wissenschaftssystem is obviously a modern distinction, which appears already in the enlightened Protestant theology ("Neologie") of the 18th century, in Johann Salomo Semler, ${ }^{17}$ and is masterfully taken up by Schleiermacher. Thus, since Semler, a strict separation between theology and lived religion has come to determine the starting point of modern Protestant theology. However, I fear that this distinction between theology, as a reflexive science, and religion, as an autonomous form in modern selfdifferentiated culture, is too strong in your system. Could it really be possible to establish such a strong separation between theology and religion? It is clear that the modern differentiation of the systems of the sciences must be maintained and theology must recognize that it is not, as such, religion. However, every theologian is both an academic and a religious, so it is sometimes difficult not to allow theology to inform and be informed by religion and vice-versa. My question in this sense is this: is it really possible to maintain such a rigid distinction between theology and religion in such a way that the boundaries between the two become impenetrable?

I raise this question because, also for Tillich, theology and lived religion are strictly separated, but not to such an extent that the boundaries become impervious. In line with Tillich, I would maintain that, as a normative presentation of the substance of a particular or positive religion, systematic theology cannot exclude lived religion. For, as a form of reflection on religious performance (Vollzug), systematic theology is aware of the irreducible duplicity of determination and performance that characterizes religion as a human phenomenon. This is because, just as the theological system elucidates, in the

\footnotetext{
${ }^{16}$ ADORNO, T. W. Aspekte. In: TIEDEMANN, R. (Hg). Gesammelte Schriften. Band 5: Zur Metakritik der Erkenntnistheorie. Drei Studien zu Hegel. Frankfurt am Main: Suhrkamp Verlag, 1990, p. 251-294, here, 251.

${ }^{17}$ On "Neologie" and Semler, cf. HORNIG, G. Johann Salomo Semler. Studien zu Leben und Werk des Hallenser Aufklärungstheologen. Tübingen: Max Niemeyer Verlag GmbH \& Co. KG, 1996.
} 
form of doctrines, the determination of a religion, also the doctrine has a supraconceptual point, given that it aspires to the immediate certainty that is performed on the human side. The contrast between theological determinacy and the immediate certainty that breaks through here is, in itself, an indication of the irreducible duplicity of both aspects. In the same way that theology, as a normative system that synthesizes the philosophical analysis of the essence of religion and the religion lived in its historical concreteness, makes use of both philosophical concepts and the intuitive character of symbols that are the direct form of expression of religious consciousness, so too religion concretely lived, through acts of faith and doctrines, intends to grasp the universality that lies at the basis of its historical realization. Undoubtedly, religion, lived in its most characteristic piety, does not need abstract concepts to express the dimension of depth that constitutes its very foundation. However, insofar as this dimension of depth that underlies religion is already presupposed in an invariable and universal manner, piety can also aspire to the immediate certainty that underlies it in an ultimate and unconditional way. By defining the ontological structural theory as a metatheory and thus distinguishing it from lived religion in his American Systematic Theology, Tillich makes room, precisely through this separation, also for a coincidence. In his words, "religious assertions do not require such a foundation for what they say about God; the foundation is implicit in every religious thought concerning God." 18 In this sense, the irreducible duplicity between determination and performance, which occupies theology as a systematic-normative enterprise, reveals itself to be equally present in lived religion. Although Tillich systematizes the distinctions between philosophy, theology, and lived religion, there is not, in the totality of his work, a separation so radical as to be insurmountable. Symbolic language itself, as the only form of expression of religion, reveals, in its constitutive structure, the distinctive interface and mutual interpenetration between philosophy, theology, and lived religion. For, insofar as every theology must make reference to a philosophy of religion as its foundational moment, and insofar as the philosophy of religion must turn to theology as its moment of concreteness and normativity, the symbol thus becomes the point of convergence par excellence between determination and performance. Religion lives in symbols. But symbols are, in turn, the direct and inauthentic form of self-expression of the universal dimension of unconditionality of subjectivity in the internal dynamics of its reflexive selfrelatedness. ${ }^{19}$ In this sense, is it really imperative that a more rigid demarcation

\footnotetext{
${ }^{18}$ TILLICH, P. Systematic Theology. Vol. I: Reason and Revelation, Being and God, p. 239.

19 These considerations on the status of Tillich's theological-systematic program were developed by me, under the decisive influence of the groundbreaking interpretation of Tillich you have been advancing in numerous texts since the year 2000, in my 2018 study on Tillich's theory of symbols. Cf., here, ABREU, F. H. Símbolo como linguagem da religião: fundamentos da teoria dos símbolos no âmbito da teoria da religião de Paul Tillich. In: TADA, E. S.; SOUZA, V. C. (Org.). Paul Tillich e a linguagem da religião. Homenagem ao Prof. Dr. Etienne Alfred Higuet. Santo André: Kapenke, 2018, p. 365-582, above all, p. 575-583.
} 
between these two spheres be proposed as the starting point for the undertaking of a systematic theology in the light of the religious plurality of democratic societies? In other words, is Tillich's system already incapable of dealing with the self-differentiation of modern culture and its system of sciences precisely because it proposes a more dynamic and less rigid relationship between theology and lived religion?

2. The second question concerns the concept of "understanding appropriation [verstehende Aneignung]," that you have been advancing as a Leitmotiv in the structuring of your new system. How does the verstehende Aneignung take place? What does it mean to appropriate the religious contents as religious contents and not as something else? Since you refer to the concept of understanding appropriation of the memory of Jesus Christ as one of the structuring moments of the Christian religious system of communication, I am not sure whether this understanding appropriation might require a further elucidation of the "conditions of possibility" which would enable subjectivity to grasp the substance of the Christian religion communication as a properly religious content and not as something else. And precisely here may lie my

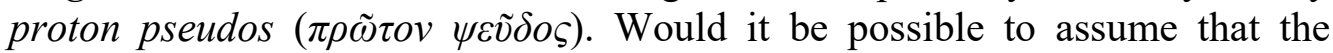
understanding appropriation happens, without at the same time, describing how subjectivity is able, de facto et de jure, to appropriate this memory as a religious event and not as an event of a different nature? That would be the case even if you successfully demonstrate that the understanding appropriation only takes place, as you can already warn your somewhat unwary readers, within the system of religious communication. After all, every apprehension - let alone an understanding one! - is an apprehension that must somehow take place in and on the bases of the constitutive conditions of individual subjectivity. In other words, could the concept of understanding appropriation be inserted into the system without being established the conditions of possibility that make this appropriation by consciousness feasible in the first place? After all, no contentual communication is pure positivity. All positivity is also always positivity for individual consciousness. The consequence of my question is rather obvious, and is entirely dependent on my intuition that the concept of verstehende Aneignung may in fact be taking the place and assuming the role of a more general concept of religious experience: a description of the understanding appropriation as a structuring moment of the Christian religion requires a theory of subjectivity that elucidates how the appropriation of a content transmitted by tradition can be assumed as a properly religious content. Perhaps, here, even if one might say, in agreement with your system, that the so-called "religious experience" takes place only within a closed system of religious communication, a theory of subjectivity, even if thematized only from a systemic-theoretical perspective, cannot be avoided if we wish to discuss the appropriation of contents as properly religious contents in any possible sense. But if this is indeed the case, then a moment that lies outside the system, and 
that makes the system of religious communication possible in the first place, would have to be affirmed - and this is precisely what you have denied. In any case, it seems to me, the concept of understanding appropriation brings with itself, as its flipside, the question of its conditions of possibility, and if that is the case it would not be possible to maintain that the understanding appropriation only occurs within a self-differentiated and autopoietic system. Rather, such an understanding appropriation would not only depend on the selfreferential system of religious communication of a content of particular grandeur and sui generis character - after all, by its very nature, religious contents, when appropriated in an understanding manner, are not contents alongside others -, but it would also be the very presupposition of the system. The result is a circularity that is not so different from those consciously present in the theories of religious experience. In other words, also in your system, it seems to me, the understanding appropriation is at the same time dependent on the system of religious communication, as well as is the basis for its structure. Without the system of religious communication there is no understanding appropriation. On the other hand, without understanding appropriation there is no system of religious communication. Such a circularity should be complexificated even further, for the verstehende Aneignung presupposes an appropriating subject. In this sense, there is not only a circularity between system and understanding appropriation, but also between understanding appropriation and the appropriating subject. Does it not mean, then, that your system, when viewed up close, takes us back to the realm of subjectivity, without which neither the system of religious communication nor the understanding appropriation would actually take place? Be this as it may, there can be no doubt that the self-relatedness of the spirit, as a constitutive feature of Tillich's concept of religion, it seems to me, is assumed and transferred, in your system, to the self-relatedness of the human spirit within a self-referential system of religious communication. The self-relatedness of the spirit is maintained, for it is only through spiritual self-relatedness that the human spirit, within an autopoietic system of religious communication, is able to reflexively grasp the universality of its own particular religion. But if this is indeed the case, then, it seems to me, a theory of subjectivity is actually presupposed. However, if this theory is brought to light, the circularities between system and understanding appropriation, as well as between understanding appropriation and the appropriating subject, may, in fact, reveal that your system also failed to evade the scope of subjectivity as the terminus a quo for the construction of a concept of religion.

3. In close connection with the first question, I would like to raise another and perhaps a more important one. Among the reasons you use to justify the need to forego building any transcendental concept of religion is its irretrievable circularity. In your book Gottes Geist, you unfold this problematic - by 
describing and dealing critically with the positions advanced by Martin Riesebrodt and, mainly, Jörg Lauster - as follows:

Religion is not just an interpretation of the reality of life stemming from the subject and its religious faculty [Vermögen], but a social action relating to suprahuman powers. Without the presupposition of a religious object level [religiösen Gegenstandsebene], the universal religion cannot be justified as a special human action that is different from others. But how do we know about divine powers if not through religion and its representational complexes? Theories of a religious experience try to answer the problem. The modern turn to the subject and its being involved [Beteiligtsein] is taken up with the concept of experience. A specifically religious experience, which, like all experience, represents an "interpretative processing of living experience [interpretierende Erlebnisverarbeitung]," and, thus, an interpreted experience, is characterized by a reference to transcendence. As a form of meaning in culture, religion arises through a sui generis experience. In this sui generis experience, a transcendent "substantial substance [substanziale $[r]$ Gehalt]" is given, which distinguishes religious experience from others and at the same time protects it from the (religious-critical) objection that it is a merely subjective interpretation [...] In terms of their logic of justification, theories of a religious experience make use of a circle, as do actiontheoretical or anthropological conceptions, in that the reference to transcendence claims something as a prerequisite for religion that is already a component and descriptive element of religious communication itself. If one wants to justify the religious field of meaning through a specific experience, then theology, which itself cannot be any experience, must already presuppose in its construction the elements that constitute the religious. In addition, theories of experience are confronted with the objection that they postulate an actual religion that can only be experienced, but which is not, however, accessible to language. ${ }^{20}$

It goes without saying that your observations about the irretrievable circularity of the modern concept of religious experience are absolutely correct. Tillich was also aware of this circularity and assumed it as unavoidable and necessary:

The theological concepts of both idealists and naturalists are rooted in a "mystical a priori," an awareness of something that transcends the cleavage between subject and object. And if in the course of "scientific" procedure this a priori is discovered, its discovery is possible only because it was present from the very beginning. This is the circle which no religious philosopher can escape. And it is by

${ }^{20}$ DANZ, C. Gottes Geist. Eine Pneumatologie, p. 117-118, [emphasis mine]. 
no means a vicious one. Every understanding of spiritual things (Geisteswissenschaft) is circular. ${ }^{21}$

This circularity referred to by Tillich is certainly present in the theories of religious experience. That is to say, the concept of religious experience must assume a transcendent sphere of meaning as a prerequisite for religion, while at the same time it makes use of this very transcendent sphere of meaning as a component and descriptive element of religious communication itself. However, would it not be possible to state that precisely this circularity is the most important circularity presupposed in our human attempts to speak of God whether at the (almost) immediate level of religious living experiences (Erlebnisse) and experiences (Erfahrungen) or at the philosophical-theological field of reflection that tries to offer a foundation for a concept of religion that, as a science, distinguishes itself without completely separating itself from lived religion in its quest to offer a critical explanation of these very religious experiences? In other words, is it not a fundamental part of religion and the science that tries to explain it (theology), to claim a sui generis experience - by nature, indomitable and ineffable -, and at the same time seek a name to symbolically encode this very experience? I am obviously aware that we cannot prove the existence of this transcendent sphere of meaning as that which is presupposed in every religious experience. Nevertheless, to what extent do religion and theology depend on "evidence" for questions that transcend the limits of critical reason (ideas)? And, more so, to what extent should theology restrict itself to what it can demonstrate scientifically - in the broad sense of Wissenschaft - without, at the same time, having to forego precisely what both lived religion and its reflexive academic interpretation (theology) assume to be the most important and fundamental element of religion? Is theology, as a science, not supposed to consciously assume and critically unfold this circularity, despite - to speak with Tillich - the "skeptical doubt" that arises from it? In other words, is theology not supposed to assume this circularity as the most fundamental one, and not a necessarily "vicious one," as Tillich says?

Naturally I am far from claiming a theology that is averse to the demands of modern academic-scientific thought. However, axiomatic assumptions, which necessarily derive from this circularity intrinsic to the theories of religious experience that you criticize and assume as the evidence for the need of a new concept of religion - a new concept which, in any case, also amounts to a circularity consciously assumed in its systemic-theoretical determination , must be taken up as such - that is to say, they must be assumed as nothing more, although nothing less, than axioms. On the other hand, are not all sciences ipso facto based on unverifiable axioms? If so, why should theology sacrifice a concept, that is claimed by lived religion itself - namely, the concept of religious experience -, only because it implies an irretrievable circularity? The circular

${ }^{21}$ TILLICH, P. Systematic Theology. Vol. I: Reason and Revelation, Being and God, p. 9. 
character intrinsic to all theories of religious experience, insofar as it is consciously assumed in its circularity and critically thematized from there, does not seem to configure a problem, as Tillich was aware. On the contrary, this very circularity seems to be the unavoidable fundamental basis for a modern theory of religion that has not yet renounced its subject and object of investigation, and still strives to offer a rigorous account of the categorial doctrine, as well as the normativity and validity of religion, as an autonomous theme of analytical inquiry, which, precisely because of its transcendental constitution, is equally underivable. In other words, is not the renunciation of the concept of religious experience, as the foundational moment of religion, equivalent to recognizing that your theological system is also going beyond its systemic self-differentiation, and moving toward offering a kind of guardianship in relation to what Christian religious communities should or should not claim as that which is most fundamental to them? Once again, I am aware that we cannot prove the truth of the transcendent realm of meaning that is constitutive of every living religion. I am also aware that you are not saying that there is no metaphysical background in religious experiences and phenomena, but only that you are unable to thematize it scientifically. However, having said that, I would insist that it is a constitutive part of religion and the search for its theoreticalcategorial explanation to have intuitions on the substance of truth claims present in religious communication systems. Apart from those intuitions, there is no living religion. On the other hand, I also do not believe that the claim to truth present at the heart of each religion is incompatible with the plurality of modern societies. On the contrary, what is incompatible with democratic societies, it seems to me, is not the truth claim present in religions, but their attempt to forcefully impose it onto others, as well as to deny the legitimacy of other forms of religious expression. By renouncing precisely this circularity, that I understand to be the most important for the critical exercise of any theological reflection, I suspect that your system - and I might be utterly mistaken - may be moving toward a form of "resignation." 22 This negative, resignative attitude could offer an explanation of why, in your system, the question regarding the genesis of religion is decidedly left out - unless, of course, the genesis of religion derives from the cultural-evolutionary process of society itself, which would be tantamount to claiming that religion is not, as such, underivable. But in so doing, i.e., by not raising the question of the genesis of religion and the constitutive role of an experience described as a properly religious one, are we not, in this movement, throwing the child out with the bathwater? After all, how are we supposed to convincingly demonstrate that religion is not a cultural

${ }^{22}$ Cf. GRÄB, W. Resignieren Philosophie und Theologie angesichts des Pluralismus der Vernunftmodelle? Ein philosophisch-theologisches Plädoyer für eine vernünftige Religion der Menschenrechte. In: DANANI, C.; PERONE, U.; RICHTER, S. (Hg.). Die Irritation der Religion. Zum Spannungsverhältnis von Philosophie und Theologie. Göttingen: Vandenhoeck \& Ruprecht, 2016, p. 123-134. 
production, an epiphenomenon of social structures, but rather "an underivable phenomenon," without consciously assuming the risk of thematizing the circularity intrinsic to the theories of religious experience as the foundational moment of religion? Is there any other way? Would it be a modified concept of revelation, but one, in any case, very close to that developed by Karl Barth, ${ }^{23}$ which would be hidden behind this systemic-theoretical refusal to thematize the genesis of religion? Or is it the scientific status of your system that prevents such a genetic theory of religious consciousness? That religion is there, i.e., that it is culturally established in a myriad of forms, is not surprising. But the reason why religion is there, and "not not-there," should certainly at least constrain us, as philosophers of religion and theologians, to seek an answer, even if, naturally, a provisory one.

4. In regard to your interpretation of Tillich, I would like to raise the following question: is it really correct to describe Tillich's attempt to offer a transcendental unity to the modern self-differentiated culture as nothing more than a mere romanticism? But even if that is the case - for the sake of the argument -, is it not the totality of modern culture, as Charles Taylor rightly pointed out, a permanent mixture of Enlightenment and Romanticism? ${ }^{24}$ Now, if the charge of romanticism comes from Carl Schmitt's description of political romanticism as a "subjectified occasionalism" that treats the world as an occasion and an opportunity for its romantic productivity, ${ }^{25} \mathrm{I}$ believe this charge

\footnotetext{
${ }^{23}$ Lest there be any further confusion, it is not the Karl Barth of the supposed "positivism of revelation" that I am referring to here. Rather, I refer to Barth's theology and his concept of revelation as reconstructed from the neo-Kantian "constellation of problems" to which he belongs. On this point, cf. WITTEKIND, Folkart. Karl Barth und die moderne Predigt: Homiletik und Glaubensverständnis bei Niebergall, Tillich und Karl Barth. Zeitschrift für Theologie und Kirche, vol. 98, no. 3, 2001, p. 344-371.

${ }^{24}$ TAYLOR, C. Sources of the Self: Making of the Modern Identity. Cambridge: Harvard University Press, 1989, p. 383: "These two big and many-sided cultural transformations, the Enlightenment and Romanticism with its accompanying expressive conception of man, have made us what we are. I don't mean this as a causal hypothesis, of course. As I have often said, the order of causation is difficult to trace in this domain. If we were looking for causes, we would have to mention a great many other things like the industrial revolution and the rise of modern nationalism. What I mean is rather that our cultural life, our self-conceptions, our moral outlooks still operate in the wake of these great events. We are still visibly working out their implications or exploring possibilities which they opened up for us. We still await another such large-scale cultural upheaval which might carry us out of their orbit, as we sense ourselves to have already departed from the orbit of Deism, Lockean or Hutchesonian, let alone such seventeenth-century notions as the divine right of kings. It is not just that we no longer believe these doctrines: we are not all unanimous about the defining doctrines of the Enlightenment or about expressivism. Rather it is that these earlier views have become strange to us; it is hard to recapture in imagination what they could ever have had going for them. Some watershed has been passed."

${ }^{25}$ Cf. SCHMITT, C. Politische Romantik. Sechste Auflage. Berlin: Duncker und Humblot, 1998, p. 19: „Die Romantik ist subjektivierter Occasionalismus, weil ihr eine occasionelle Beziehung zur Welt wesentlich ist, statt Gottes aber nunmehr das romantische Subjekt die zentrale Stelle einnimmt und aus der Welt und allem, was in ihr geschieht, einen bloßen Anlaß
} 
is even more problematic, for it would have to assume not only Schmitt's diagnosis of individualistically disintegrated societies (secularization), ${ }^{26}$ but also his description of romanticism's ego-imperialism as a mere reaction against the despair occasioned by the new natural science and consequential disenchantment of the lifeworld. Such a reading of the German post-Kantian philosophical and theological tradition, as you are well aware, does not do justice to the reasons that led critical thinking to the Copernican turn that elevated subjectivity to the center of its world. Furthermore, is it not precisely Schmitt's Caesarist construction of the concept of the state that can easily be denounced as nothing more than an unbridled romanticism promoted by a subjectified occasionalism? ${ }^{27}$ For, if the diagnosis offered by Schmitt is correct, then the entire philosophical tradition of the Enlightenment is nothing more than mere romanticism. This could easily lead us to the rather uncanny and paradoxical thesis that Western civilization and its tradition of thought have never really been able to realize that, in fact, "nous n'avons jamais été modernes. ${ }^{28}$ But with this I fear that the fundamental reasons of modernity and its overwhelming and all-encompassing inflection are so caricatured that we will no longer know what we are talking about when we refer to the Enlightenment and "modern culture." 29

Now, if Tillich is not trying to offer a foundation for the modern selfdifferentiated and autonomous culture by means of a mere romantic reaction and heteronomous attack against its very autonomy, then why would Tillich's theology of culture be incompatible with the pluralism of modern societies? Particularly, I do not believe that the search for a transcendental unity between

macht. Dadurch, daß die letzte Instanz sich von Gott weg in das geniale ,Ich“ verlegt, ändert sich der ganze Vordergrund und tritt das eigentlich Occasionalistische rein zutage“.

${ }^{26}$ Against the secularization-diagnosis of modern societies, cf. GRÄB, W. Resignieren Philosophie und Theologie angesichts des Pluralismus der Vernunftmodelle? Ein philosophischtheologisches Plädoyer für eine vernünftige Religion der Menschenrechte, above all, p. 125131.

${ }^{27}$ A common reproach against Schmitt is that he is guilty of the same sins which he condemns in others. One well-known example is Leo Strauss's contention that Schmitt's analysis of the concept of the political remains within the "horizon" of the liberalism it is intended to undermine. Cf. STRAUSS, L. Anmerkungen zu Carl Schmitt, Der Begriff des Politischen. In: MEIER, H. (Hg.). Carl Schmitt, Leo Strauss und »Der Begriff des Politischen«. Zu einem Dialog unter Abwesenden. Dritte Auflate. Stuttgart; Weimar: J. B. Metzler'sche Verlagsbuchhandlung; Carl Ernst Poeschel Verlag GmbH, 2013, p. 99-125. In this connection, cf. also LÖWITH, Karl. «Der okkasionelle Dezisionismus von C. Schmitt». (1935). In: Sämtliche Schriften. Band 8: Heidegger - Denker in dürftiger Zeit. Zur Stellung der Philosophie im 20. Jahrhundert. Stuttgart: J. B. Metzler'sche Verlagsbuchhandlun), 1984, p. 3271.

${ }^{28}$ Cf. LATOUR, B. Nous n'avons jamais été modernes. Essai d'anthropologie symétrique. Paris: Éditions La Découverte \& Syros, 1997, p. 19-22.

${ }^{29}$ Cf. BARTH, U. Religion in der europäischen Aufklärung. In: BARTH, U.; DANZ, C.; GRÄB, W.; GRAF, F. W. (Hg.) Aufgeklärte Religion und ihre Probleme. Schleiermacher Troeltsch - Tillich. Berlin; Boston: Walter de Gruyter GmbH, 2013, p. 91-112. 
religion and culture is pernicious to the plurality of modern culture, nor do I read it as a mere romantic reaction promoted by a "subjectified occasionalism." Neither is the affirmation of the truth of religions - or, for that matter, the claim to absoluteness of one's own religion - incompatible with the pluralistic constitution of democratic societies in any sense whatsoever. On the contrary, the relativism of "anything goes," as far as I can see - and especially bearing in mind my own Brazilian context -, is far more pernicious to democratic societies than a critically measured and methodically controlled attempt to demonstrate the truth of religion. Again, Tillich's attempt to offer a theoretical foundation, based on a philosophy of spirit, for the essential unity - which, however, is the basis for the actual distinction - between religion and culture, does not seem to pose any danger to the pluralist conformation of modern democratic societies. Tillich, if I understand him correctly, is careful enough both to not allow cultural heteronomy interfere with the autonomy and self-determination of religion, and to warn, ab ovo et initio, against any religious attempt to provide a heteronomous control and tutelage of the autonomous modern culture. Obviously this is not to say that for Tillich there are no areas of tension between religion and culture. On the contrary, it is not possible to assert, in my understanding, that the necessary interrelatedness between religion and culture results in an unbroken harmonic relationship - which is exactly what a romantic spiritual reaction fostered by a subjectified occasionalism would postulate and aim for. In contrast, religion and culture are, in Tillich's philosophicaltheological thinking, in a differentiated relationship of reciprocal coordination, which Tillich conceptually encapsulates under the terms autonomy, heteronomy, and theonomy. This form of interrelatedness between religion and culture is Tillich's cultural-theological ideal, and not a description of a determinate state of affairs, for the risks of the self-assertion of a heteronomous or a self-sufficient autonomous culture remain always a possibility. For this reason, and for this careful conceptual demarcation, it is difficult to see why Tillich's program would be incompatible with the pluralism of modern democratic societies. At the same time, his system not only offers us an interpretative key that allows us to demarcate these areas of tension with particular perceptiveness, but also provides the religious theorist with an analytical tool capable of submitting any and all heteronomous postures to an unconditional judgment. After all, "true religion" knows that the perfect unity of forms of meaning is, and must remain, a "symbol," 30 and not a reality de

30 Cf. CORDEMANN, C. Religion und Kultur. Paul Tillichs religionsphilosophische Grundlegung einer Theologie der Kultur. In: DANZ, C.; SCHÜßLER, W. (Hg.). Paul Tillichs Theologie der Kultur: Aspekte, Probleme, Perspektiven. Berlin; Boston: Walter de Gruyter $\mathrm{GmbH} \& \mathrm{Co}$ KG, 2011, p. 103-104. Although true religion knows that the perfect unity of forms of meaning is a symbol, the danger of identifying the unconditioned with the conditioned forms of meaning remains a permanent threat. As CORDEMANN, C. Religion und Kultur. Paul Tillichs religionsphilosophische Grundlegung einer Theologie der Kultur, p. 103-104 points out: „Die Gefahr einer theonomen Geisteslage liegt darin, dass sie die Formen, in denen sie einmal 
facto. This is the reason why religion, from the vantage standpoint of the unconditioned, must, at the same time, affirm and negate such a symbol of a perfect unity. ${ }^{31}$ It affirms it as an unreachable ideal toward which the spirit continuously strives in its "meaning fulfillment structure" (Sinnerfüllungsstruktur); but it also negates it, and must negate it, as an actual possibility, precisely because religion knows that the unconditioned is no object to be grasped.

5. Another aspect that is worth noting in your lecture is that you seem to have taken the self-differentiation process of modern culture into different subsystems for granted. However, I wonder, how far this description is to be maintained, especially in regard to countries characterized by a "peripheral modernity," as it is the case with Brazil? In the Brazilian context, it remains clear that the different social subsystems extend their limits into other subsystems in such a way as to prevent their reproduction. In peripheral modernity - and I would like to raise the question as to what extent this is also not the case in Europe and the United States, even if in a more somewhat controlled manner -, it is much easier to observe the existence of "allopoietic" than properly autopoietic systems. This state of affairs is very well described by the Brazilian jurist Marcelo Neves in his book Verfassung und Positivität des Rechts in der peripheren Moderne: Eine theoretische Betrachtung und eine Interpretation des Falls Brasilien. ${ }^{32}$ Instead of systemic self-differentiation, Neves brings up the concept of "systemic corruption" - by the way, a concept so well-articulated that Luhmann himself seems to have been forced to start a process of revising his systems theory in the late period of his intellectual production. ${ }^{33}$

den adäquaten Ausdruck des Gehaltes sah, zu konservieren sucht. Die lebendige Theonomie, die überall den unbedingten Gehalt des Wirklichen aufspürt, steht nach Tillich immer in Gefahr, allmählich zu erstarren und die bedingten Formen, die einst Symbol des Unbedingten waren, selbst absolut zu setzen“.

${ }^{31}$ Cf. TILLICH, P. Religionsphilosophie. (1925). In: CLAYTON, J. P. (Hg.). Main Works Hauptwerke. Band 4: Religionsphilosophische Schriften. Berlin; New York: Walter de Gruyter; Evangelisches Verlagswerk, 1987, p. 145-146: „Religion ist Richtung des Geistes auf den unbedingten Sinn, Kultur is Richtung des Geistes auf die unbedingten Formen. Beide aber treffen sich in der Richtung auf die vollendete Einheit der Sinnformen, die für die Kultur Abschluß ist, für die Religion aber Symbol, das vom Unbedingten her zugleich bejaht und verneint wird".

${ }^{32}$ Cf. NEVES, M. Verfassung und Positivität des Rechts in der peripheren Moderne: Eine theoretische Betrachtung und eine Interpretation des Falls Brasilien. Berlin: Duncker und Humblot, 1992.

${ }^{33}$ Cf. LUHMANN, N. Zur Einführung. In: NEVES, M. Verfassung und Positivität des Rechts in der peripheren Moderne: Eine theoretische Betrachtung und eine Interpretation des Falls Brasilien, p. 1-4; LUHMANN, N. Inklusion und Exklusion. In: Soziologische Aufklärung. Band 6: Die Soziologie und der Mensch. Opladen: Westdeutscher Verlag GmbH, 1995, p. 237264. 
The concept of systemic corruption developed by Neves describes a structural conjuncture that affects expectations regarding the social system within the scope of social expectations provided by the process of systemic selfdifferentiation of modern societies. Legal selection in these contexts does not occur autonomously, i.e., by the autopoeitically reproduced "legal-illegal [Recht-Unrecht]" code. Other codes and social interests block this reproduction. Politics and economics "invade" or "overexploit" the legal system, for example, which can no longer reproduce itself autonomously. Thus, instead of legal communications operating by their code, the legal system becomes permeated by codes such as "having-not having," "property-non-property," and "being able-unable," or even by selections of particularist networks, such as "friendnon-friend" or "boss-client," in addition to favoring networks and patronage relationships. The systemic corruption argument should not be confused with an homage of liberalism or a formalist argument of legality, as systemic corruption in an "allopoietic law" - or one that has had moments of allopoiesis considerably obstructs the ability to provide mechanisms for modern social inclusion patterns across the board. It is for this reason that Neves analyzes the positivity of the law, the effectiveness of the Constitution, and the true role of social rights. The analysis does not fall on Brazilian society only, but postulates that, in certain regions of the globe, the mechanisms of social inclusion - such as citizenship, welfare state, constitutional rule of law, social rights, political inclusion, etc. - present serious deficits in relation to its formulation and implementation.

For this reason, Luhmann's description of the welfare state as the achievement of political inclusion as a result of the "sociological principle of inclusion," strikes me as too problematic when applied to the so-called "Global South." The "old" Luhmannian concept of inclusion, developed in $1981,{ }^{34}$ was defined by the scope of the entire population in the performances of individual functional systems. For Luhmann, the sociological principle of inclusion relates, on the one hand, to the access of the benefits of a system and, on the other, to dependence on the ways of life that a certain system imposes. The marginalization of population segments from systemic benefits would configure the concept of "exclusion." Turning Luhmann upside down, Neves argues that, in contexts of peripheral modernity - more extensive in territory and population than the so-called "center of modernity" -, it would be better to recognize the predominance of the "sociological principle of exclusion," so that it would not be possible to affirm that the fundamental rights would be generalized in the scope of action and experience of the population, nor would they serve as guidelines for their normative expectations. ${ }^{35}$ Thus, the author starts from the

\footnotetext{
${ }^{34}$ Cf. LUHMAnN, N. Political Theory in the Welfare State. Berlin; New York: Walter de Gruyter \& Co, 1990, p. 34-39.

${ }^{35}$ Cf. NEVES, M. Verfassung und Positivität des Rechts in der peripheren Moderne: Eine theoretische Betrachtung und eine Interpretation des Falls Brasilien, p. 215.
} 
structural heterogeneity of the so-called "world society [Weltgesellschaft]" described by Luhmann, ${ }^{36}$ and the "marginalization of the masses," to discuss relations of sub-integration and over-integration. These relations are, according to Neves, typical of peripheral contexts, especially in regards to the generalization of citizenship. Therefore, it would not be enough just to analyze the "marginalized," since the sub-integration of the masses is inseparable from the over-integration of privileged groups. In this context, the marginalized are seen as sub-citizens already sub-integrated into the legal system, for whom fundamental rights are not effective and are not implemented. For the subintegrated, the constitutional provisions have relevance almost exclusively in their restrictive effects on freedoms. They are integrated into the system, as a rule, already in a position of condemned and marginalized, and not as agents with constitutional rights. ${ }^{37}$ Legalism is harshly imposed upon them, mainly by

\footnotetext{
${ }^{36}$ LUHMANN, N. Die Weltgesellschaft. Archiv für Rechts- und Sozialphilosophie/Archives for Philosophy of Law and Social Philosophy, 1971, vol. 57, no. 1, 1971, p. 1-35.

${ }^{37}$ Cf. NEVES, M. Verfassung und Positivität des Rechts in der peripheren Moderne: Eine theoretische Betrachtung und eine Interpretation des Falls Brasilien, p. 79: „In einer systemtheoretischen Perspektive bedeutet ,Marginalität" eine diffuse und sehr instabile soziale Subintegration eines großen Bevölkerungsteils in die verschiedenen Leistungssysteme, die sich mit der peripheren Modernisierung verschärft. "Subintegration" heißt hier praktische Blokkierung des positiven ( $=$ im eigenen Interesse des Handelnden) Zugangs zu den bestehenden modernen sozialen Systemen (Wirtschaft, Politik, Recht, Erziehung u. s. w.), die dann hauptsächlich nur negativ die ,Marginalisierten“ betreffen (z. B. als Schuldner, nicht als Gläubiger; als Angeklagte, nicht als Kläger). In Anlehnung an Luhmann läßt sich ,Marginalisierung' als Exklusion bezeichnen, allerdings nicht im Sinne von Nicht-Integration ganzer Bevölkerungsgruppen, sonders als deren Abhängigkeit von ohne Zugang (im positiven Sinne) $z u$ den Leistungen der unterschiedlichen Funktionssysteme der Gesellschaft (Subintegration) [...] Ein Einwand gegen die Behauptung der Existenz von Flexibilität und Zukunftsoffenheit in peripheren Gesellschaften wäre anhand des Argumentes geltend zu machen, daß das Konzept der ,Marginalität ${ }^{\star}$ damit nicht vereinbar ist, insoweit die ,Marginalisierten“ (der größte Teil der Bevölkerung) subintegriert in die modernen sozialen Systeme sind, also über sehr begrenzte Handlungsmöglichkeiten verfügen. Obgleich unter handlungstheoretischer Perspektive dieses Argument als richtig anzusehen ist, nehmen die Begriffe der Flexibilität, Kontingenz und Zukunftsoffenheit eine systemtheoretische Bedeutung in der vorliegenden Untersuchung an: Sie gehen auf die Überzahl an Systemvariablen und damit verbunden auf die im Interaktionszusammenhang systemselektiv zu verwirklichenden oder auszuschaltenden umweltlichen Möglichkeiten zurück. Strukturiert das System adäquat die Komplexität seiner jeweiligen Umwelt, so wird eine positive (relativ sichere) Flexibilität und Zukunftsoffenheit geschaffen. Versagen die sozialen Systeme im Gegenteil dabei, die Überkomplexität ihrer Umwelt zu bestimmen (wie in den peripheren Gesellschaften unbestreitbar), dann entstehen negative (relativ unorganisierte) Flexibilität und negative (relativ unkontrollierbare) Kontingenz/Zukunftsoffenheit, also fehlt es an gesellschaftlicher Sicherheit. So kann z. B. ein Ehepaar unter instabilen wirtschaftlichen Bedingungen nicht sicher sein, ob die Familie mit dem monatlichen Haushaltsbudget (wenn so etwas möglich ist) auskommt, ein beraubter Unterbeschäftigter nicht sicher damit rechnen, ob er im Fall des Beklagens bei der Polizei ,gut‘ (gesetz- bzw. verfassungsmäßig) behandelt wird, der Wahlsieger nicht mit Sicherheit erwarten, daß er das Amt antritt (die Bedrohung eines Putsches ist immer vorhanden!)“.
} 
the repressive activity of the state apparatus. In terms of the theory of inclusion initially developed by Luhmann, but now revised from peripheral modernity, it could be said that the relationship between the sub-integrated and the legal system is one of dependence without access. On the other hand, the overintegrated would constitute privileged groups that, often with the support of the state bureaucracy, would develop actions blocking the autonomous reproduction of the right in order to maintain privileges. This state of affairs means access without dependence, configuring the corrupt use of privileges and illegalities, with impunity being its distinctive mark.

Obviously, I would not like to fill this modest reaction to your lecture with theoretical approaches drawn from public law theory. However, the description of the functioning of Brazilian peripheral modernity serves to demonstrate that Luhmann's description of the social system must be, at the very least, problematized. On the other hand, if this state of affairs describes the interpenetration of different social subsystems, thinking about religion in Brazil requires an exercise that takes into account the fact that religion is often so informed by the code of the political system - and vice-versa! - that the question of its nature becomes inevitable. In this way, I believe a categorial analysis as well as the formulation of standards of judgment of validity and normativity cannot fail to occupy theology as a critical reflection. Depriving theology of the right it has, as an academic critical reflection, to provide a yardstick for the task of the "discrimination of the gods," can result in a form - and here, indeed, a dangerous one! - of "theological aristocratism." It is not uncommon for religion to be severely criticized in the name of "true religion." Here, I believe, abandoning the standard of judgment stemming from the principle of the "finite freedom" may deprive theology and theologians of their critical role - also in society. After all, in times of such acute social polarization in which constitutional guarantees are suspended and human rights are not only questioned but also systemically violated - with the rather "ideological" support of very problematic understandings of religion, morality, and nation! -, is the theologian, in order to maintain his autopoietic purity, supposed to remain silent? ${ }^{38}$ My fear is that if we dare to relinquish standards of judgment that allow us to develop a criterion for the task of the "discrimination of the gods," we will no longer be able to point out the very nature of religion and its distinction from other social subsystems. On the other hand, without a rigorous concept of religion as well as a standard of judgment for the task of the discrimination of

\footnotetext{
${ }^{38}$ Also in this direction, Tillich continues to be an example for the social responsibility of the theologian, even if I am referring here to a private letter. Cf. TILLICH, P. Die Theologie des Kairos und die gegenwärtige geistige Lage. Offener Brief an Emanuel Hirsch von Paul Tillich. In: ALBRECHT, R.; TAUTMANN, R. (Hg.). Ergänzungs- und Nachlaßbände zu den Gesammelten Werken von Paul Tillich. Band VI: Briefwechsel und Streitschriften. Theologische, philosophische und politische Stellungnahmen und Gespräche. Frankfurt am Main: Evangelisches Verlagswerk, 1983, p. 142-176. Nonetheless, one could easily find more sources in Tillich's political writings.
} 
the gods, theology - and the religious communities themselves - tends to become, as usually is the case or even the rule, a form of socio-political pedagogy, and not a methodologically controlled reflection on its conditions of possibility as a university science. The public discourse of religious communities, informed by sociogenetic conditionings of all sorts, is elevated to the status of academic theology. With this, it is clear that not only the systemic self-differentiation is highly problematic in contexts of peripheral modernity, but also the self-differentiation of the Wissenschaftssystem, insofar as we are no longer able to demarcate with the required precision the necessary distinction between theology and lived religion or the public discourses of the distinct religious communities. Often, both religious discourse and theological discourse - if it is still possible to identify their distinctions in any sense whatsoever - can be summed up, in terms of their substantive content, as no more than pamphlets of competing political parties. The religious-theological norm, therefore, seems to be found above all in its relevance to political militancy!

6. When you propose that it is in the use of religious communication that the contents of the Christian religion can be distinguished from other cultural communications, I confess that I feel a little uncomfortable. This is because there are many different uses of religious content that are sometimes not only contrasting, but are on a true collision course. As mentioned above, it is very difficult to distinguish between religion and politics in societies of peripheral modernity - although not only. The social and political history of the United States can serve as an example here - and this state of affairs, far from being a historically settled issue, remains a shaping feature of the construction of American sub-citizenship. ${ }^{39}$ If the religious norm is to be found in the use of religious communication, how to distinguish, for example, between religion and politics in the context of the struggle for civil rights in the USA? Who would be able to pinpoint exactly where politics began and ended for someone like Martin Luther King Jr., for example - or, for that matter, James Cone? ${ }^{40}$ The same applies to Latin American Liberation Theologies and their vast history of social engagement. On the other hand, we can observe in Brazil the advance of a political religion with an ultra-authoritarian predisposition. It is clear that religious communication is mixed with political communication. However, it is

\footnotetext{
39 Added to this are other even more complex factors that throw the democratic statute of American society into remarkable fragility. In this connection, cf. RUNG, D. L. Processes of Sub-Citizenship: Neoliberal Statecrafting 'Citizens,' 'Non-Citizens,' and Detainable 'Others'. Social Sciences, no. 1:5, vol. 9, 2000, p. 1-30.

${ }^{40} \mathrm{Cf}$., for instance, ROYAL, Z. Cultural Transformation as Ultimate Concern: Tillich in Conversation with the Black Liberation Theology of James Cone. In: BANDY, T. G. (Ed.). Why Tillich? Why Now? Macon: Mercer University Press, 2021, p. 265-275, although I think that an approximation between Tillich and Cone operated in this way completely obliterates not only the idealist and neo-Kantian foundations of Tillich's theology, but also the systematic intent of Cone's theology.
} 
practically impossible to delineate where religion begins and politics ends when the yardstick lies in its use only.

Therefore, I find it extremely difficult to renounce the role of the Religionskritik as a founding and indispensable moment in theology. In my view, the function of the enlightened critique of religion must undoubtedly be assumed and continued in the present. However, for this exercise to have any success, the critique of religion must be carried out in a very different manner, for it can no longer rely on the authority of the Bible (Schriftprinzip). Modernity, unlike what the old theories of modernization and social theories of evolution anticipated, proved to be an extraordinarily productive time in "religious matters." ${ }^{41}$ Even in Europe, although generally described by theorists of modernity as a special case, ${ }^{42}$ since the 18 th century, profound transformations and displacements can be easily identified both in the religious field and in religious semantics. Modernization impulses, as the perspective of the history of European religion demonstrates, are always accompanied by resacralization and re-enchantment of the world, even though both the idea of resacralization

${ }^{41}$ Cf. GRÄB, W. Resignieren Philosophie und Theologie angesichts des Pluralismus der Vernunftmodelle? Ein philosophisch-theologisches Plädoyer für eine vernünftige Religion der Menschenrechte, p. 126: „Von einem ,säkularen Zeitalter ${ }^{\star}$ zu reden, will mir im Blick auf die moderne Weltgesellschaft jedenfalls gänzlich abwegig vorkommen. Die Aufklärung hat ein solches nicht heraufgeführt. Auch wer lediglich davon meint reden zu müssen, dass mit der Moderne dem Glauben eine säkulare Alternative erwachsen sei, der übersieht völlig, dass mitten in dieser angeblich so säkularen, vom Glauben abfallenden Moderne, der Religion ganz neue Kräfte zugewachsen sind. Rückzugstendenz und Verfallserscheinungen lassen sich allenfalls am nordatlantischen Kirchentypus des Christentums feststellen, gleichermaßen in seiner römischkatholischen wie in seiner protestantischen Spielart. Die Ausrufung des säkularen Zeitalters lebt denn auch ganz und gar von der Gleichsetzung der Religion mit der Kirche und ihren Glaubensregeln. Aber auch die Rede von postsäkularen Verhältnissen gesteht der Religion in der sich immer weiter säkularisierenden Gesellschaft nur eine sehr eingeschränkte Bedeutung zu. In der Rede von der postsäkularen Gesellschaft verdient der Glaube die Anerkennung der Säkularen, weil er angeblich über lebensführungspraktisch relevante Motivationspotentiale verfügt, die den säkularen Bürgern nicht zur Verfügung stehen. Den Säkularen wird aber zugleich versichert, dass sie die religiöse Rede etwa von der Welt als Gottes Schöpfung nur dann etwas angehe, wenn es den Religiösen gelingen sollte, die religiöse Rede in ihrem vernünftigen Gehalt explizieren zu können. Es bleibt dabei, der Glaube ist für die heutigen Hüter der Vernunft zumeist nur eine Angelegenheit für die Gläubigen. Den Säkularen ist keinesfalls die Einsicht zuzumuten, dass der Glaube auch etwas sie selbst Angehendes sein könnte. Die Säkularen haben vielmehr weiterhin die Vernunft auf ihrer Seite, auch wenn mit der Postsäkularismusthese das Empfinden sich bemerkbar macht, dass die Vernunft möglicherweise nicht mit sich allein sein könnte, sondern selbst auch einen Glauben bei sich hat".

42 On the particularity of the theme of secularization in Europe, cf. KNOBLAUCH, H. Ganzheitliche Bewegungen, Transzendenzerfahrung und die Entdifferenzierung von Kultur und Religion in Europa. Berliner Journal Für Soziologie, 12, 2002, p. 295-307; EDER, K. Europäische Säkularisierung - ein Sonderweg in die postsäkulare Gesellschaft? Berliner Journal Für Soziologie, 12, 2002, p. 295-307; POLLACK, D. Säkularisierung - ein moderner Mythos? Studien zum religiösen Wandel in Deutschland. Tübingen: J. C. B. Mohr (Paul Siebeck), 2003, above all, p. 1-18. 
and re-enchantment must be problematized. ${ }^{43}$ The Enlightenment brings Romanticism with it as the other of itself, as Charles Taylor aptly described it. On the other hand, Max Weber coined the metaphor of the "Kampfes der Götter," 44 in order to describe the conflicts in debates about self-interpretation vis-à-vis the individual orders and values of the modern era. Also in the present, the most different gods constantly fight among themselves for recognition. The modern struggle of the gods is by no means restricted, however, only to Islam, or Pentecostalism and neo-Pentecostalism, although those forms of religion have received much more media attention. On the contrary, the modern struggle of the gods concerns, ipso facto, Christianity - in all its forms, including more traditional ones. In the obscurity of the modern age, only the most rigid and authoritarian forms of Christianity are on the rise $\mathrm{s}^{45}$ - and this is the only meaning I can ascribe to the rather colorful theme of the "return of the gods." Such forms offer individuals not only clear distinctions between "good" and "bad," "right" and "wrong," as well as a dense sense of communitarization, but also promise a stable identity, combined with a worldview capable of resistance

\footnotetext{
${ }^{43}$ Cf. LEHMANN, H. Von der Erforschung der Säkularisierung zur Erforschung von Prozessen der Dechristianisierung und der Rechristianisierung im neuzeitlichen Europa. In: LEHMANN, H. (Hg.): Säkularisierung, Dechristianisierung, Rechristianisierung im neuzeitlichen Europa. Bilanz und Perspektiven der Forschung. Göttingen: Vandenhoeck \& Ruprecht, 1997, p. 9-16; GRAF, F. W. Die Wiederkehr der Götter: Religion in der modernen Kutur. München: Verlag C. H. Beck, 2004, p. 15-18, 69-101; GRAF, F. W. Der eine Gott in vielerlei Gestalt. Die konfliktreiche Pluralisierungsdynamik in den drei monotheistischen Religionen. In: GALL, L.; DIETMAR, W. (Hg.). Judaism, Christianity, and Islam in the Course of History: Exchange and Conflicts. München: R. Oldenbourg Verlag, 2011, p. 1-17.

${ }^{44}$ WEBER, M. Wissenschaft als Beruf. In: MOMMSEN, W. J.; SCHLUCHTER, W. (Hg.). Max Weber Gesamtausgabe. Band 17. Abteilung I: Schriften und Reden. Tübingen: J. C. B. Mohr (Paul Siebeck), 1992, p. 101.

${ }^{45}$ Cf. LAUSTER, J. Liberale Theologie: Eine Ermunterung, p. 305: „Was gegenwärtig alles als Rückkehr der Religion oder als Wiederkehr der Götter beobachtet und mitunter auch von kirchlicher und theologischer Seite hoffnungsfroh herbeigeredet wird, hat mit der Grundhaltung liberaler Religiosität wenig gemeinsam. Ich kann wenigstens in diesem Punkt den Optimismus mancher Kirchenleitung nicht teilen, dass die evangelische Kirche aus dieser Rückkehr der Religion glanzvoll auferstehen wird. Denn diese besagte Rückkehr ist im Wesentlichen vor allem eines: eine Refundamentalisierung religiöser Praxis. In der Suche nach letzter Orientierungsgewissheit wird die Unterscheidung in Offenbarungsgrund und Offenbarungsausdruck eingezogen, vorletzte, menschliche Ausdrucksformen werden mit dem letztgültigen Grund der Religion verwechselt, für absolut gesetzt und bisweilen geradezu magisch aufgeladen. Eine auf vernünftige Transparenz setzende Religiosität, die die Begrenztheit und Vorläufigkeit menschlicher Religionsformen anerkennt, hat in diesem Klima keinen leichten Stand“.
} 
to the crisis, for those who suffer the constraints imposed by the "iron cage [stahlhartes Gehäuse]" 46 of modern rationality. ${ }^{47}$

The gods resurrected from their graves, who resume their eternal war in the modern lifeworld, raise the question of which religion and which gods we wish to tolerate, or not tolerate. With the task of the divine discrimination, the ancient distinction between true religion and false religion has returned to the agenda of modern societies. ${ }^{48}$ Of course, the question of true religion can no longer be decided, as mentioned above, simply by referring to the "inspired Bible" or other authoritative sources. The conditions for formulating a validity judgment about religion's truth claims are, in modernity, much more complex. Criticism, as none other than Immanuel Kant has demonstrated with remarkable accuracy, presupposes a yardstick $(M a \beta t a b)$ of judgment by which "knowledge can be distinguished with certainty from illusory knowledge." 49 If the validity judgment really desires to avoid the risk of the one-sidedness of a pure and simple decisionism, it must be accessible to rational argumentation. Of course, as Kant emphasized in his 1793 Religionsschrift, ${ }^{50}$ this judgment also applies to religion. However, every standard of judgment, as the bicentennial debates over an appropriate concept of religion clearly reveal, depends on a specific sociocultural perspective. In any understanding of the concept of religion, as the classic methodological reflections on the objectivity of knowledge in the social sciences developed by Simmel, Weber, and Troeltsch show, normative convictions are always and invariably present. ${ }^{51}$ Normative aspects are always

\footnotetext{
${ }^{46}$ WEBER, M. Die protestantische Ethik und der „Geist“ des Kapitalismus. Neuausgabe der ersten Fassung von 1904-05 mit einem Verzeichnis der wichtigsten Zusätze und Veränderungen aus der zweiten Fassung von 1920. Herausgegeben und eingeleitet von Klaus Lichtblau und Johannes Weiß. Wiesbaden: Springer VS, 2016, p. 171.

${ }^{47}$ GRAF, F. W. Die Wiederkehr der Götter: Religion in der modernen Kutur, p. 29.

${ }^{48}$ Here I am referring our readers to an "old" text of yours - DANZ, C. Vera et falsa religio. Zum Verhältnis von Religions- und Geltungstheorie in der Religionstheologie. In: DANZ, C.; HERMANNI, F. (Hg.). Wahrheitsansprüche der Weltreligionen. Konturen gegenwärtiger Religionstheologie. Neukirchen-Vluyn: Neukirchener Verlagsgesellschaft, 2006, p. 191-210.

${ }^{49}$ KANT, I. Prolegomena zu einer jeden künftigen Metaphysik, die als Wissenschaft wird auftreten können. In: WEISCHEDEL, W. (Hg.). Immanuel Kant. Werke in zehn Bänden. Sonderausgabe. Band 5: Schriften zur Metaphysik und Logik. Darmstadt: Wissenschaftliche Buchgesellschaft, 1983, p. 109-264, here, p. 263.

${ }^{50}$ Cf. KANT, I. Die Religion innerhalb der Grenzen der bloßen Vernunft. In: WEISCHEDEL, W. (Hg.). Immanuel Kant. Werke in zehn Bänden. Sonderausgabe. Band 7: Schriften zur Ethik und Religionsphilosophie. Zweiter Teil. Darmstadt: Wissenschaftliche Buchgesellschaft, 1983, p. 645-879.

${ }^{51}$ SIMMEL, G. Zur Soziologie der Religion. Neue Deutsche Rundschau (Freie Bühne), 9, 1898, p. 11-123; SIMMEL, G. Die Religion. Frankfurt am Main: Literarische Anstalt Rütten \& Loening, 1906; WEBER, M. Die Objektivität sozialwissenschaftlicher und sozialpolitischer Erkenntnis. (1904). In: Gesammelte Aufsätze zur Wissenschatslehre. Tübingen: Verlag von J. C. B. Mohr (Paul Siebeck), 1922, p. 146-214; TROELTSCH, E. Was heißt „Wesen des Christentums“?. In: Gesammelte Schriften. Zweiter Band: Zur religiösen Lage, Religionsphilosophie und Ethik. Tübingen: Verlag von J. C. B. Mohr (Paul Siebeck), p. 386-
} 
incorporated in the understanding of religion, so that any supposed "neutrality" in the analysis of the religious phenomenon is nothing more than a chimera. As the history of the academic study of religion demonstrates, not only philosophers of religion and theologians, but also scientists of religion, ${ }^{52}$ always and invariably make value judgments about the religious phenomenon in question. Here, the oft-observed "neutrality paradox" comes into play: the neutral point of view is itself a point of view and can only be described as "neutral" in relation to other points of view. Thus, even the most empiricist science of religion can only observe the religious phenomenon and, therefore, build categorial distinctions, starting from a determined place. ${ }^{53}$

The problematic described above brings me to one of the last questions I would like to ask about your theological system. Considering that the concept of religion must be restricted to Christianity, and that, due to the systemic selfdifferentiation of religion, we can only have "plural descriptions" of the meaning of the Christian religion, would your system be free from the vulnerabilities of relativism - if not from a substantive relativism, at least, however, from a functional one? If we abandon an external criterion for the task of the "discrimination of the gods," do we not run the risk of having to accept any and every self-description that claims to be religious? For precisely this is the consequence of the absence of a yardstick of judgment for the critical task of discrimination of the gods - namely, any and all forms of religious selfdescription must be regarded as such. In my understanding, however, it is only through an absolutely rigorous and universal concept of religion that the true and authentic religious plurality of democratic societies can be maintained. The real opposition does not lie, as far as I understand, between absolutism and pluralism, where by "absolutism" is understood, both a veiled form of totalitarianism and imperialism, and by "pluralism" is understood, the affirmation of relativism. This opposition is, in my view, absolutely false. The real opposition lies between pluralism and relativism, insofar as real relativism is the true opposite of pluralism, for what characterizes pluralism is the recognition of the legitimacy of many divergent and contrasting positions. The keyword here is "legitimacy," because while in true pluralism the legitimacy of

451; TROELTSCH, E. Wesen der Religion und der Religionswissenschaft. In: Gesammelte Schriften. Zweiter Band: Zur religiösen Lage, Religionsphilosophie und Ethik, p. 452-499. On the continuing relevance of the perspectives of Troeltsch, Simmel and Weber, cf. KRECH, V. Wissenschaft und Religion: Studien zur Geschichte der Religionsforschung in Deutschland 1871 bis 1933. Tübingen: J. C. B. Mohr (Paul Siebeck), 2002, p. 23-37.

${ }^{52}$ Cf. SCHLIETER, J. Religion, Religionswissenschaft und Normativität. In: STAUSBERG, M. (Hg.). Religionswissenschaft. Berlin; Boston: Walter de Gruyter GmbH \& Co. KG, 2012, p. 227-240; FREIBERGER, O. Ist Wertung Theologie? Beobachtungen zur Unterscheidung von Religionswissenschaft und Theologie. In: LÖHR, G. (Hg.). Die Identität der Religionswissenschaft: Beiträge zum Verständnis einer unbekannten Disziplin. Frankfurt am Main: Peter Lang, 2000, p. 97-121.

${ }^{53}$ SCHLIETER, J. Religion, Religionswissenschaft und Normativität, p. 237. 
different positions is recognized, in true relativism, in turn, no position is legitimate, i.e., there is no legitimate principle insofar as every single principle is, $a b$ ovo, equally false. All concrete positions are equal precisely because there is no possible legitimate principle. In this sense, although taking the plurality of religious expressions as a starting point, your system seems to me to advance much more toward the "universalization of particularism" - that is, true relativism - than assuming the plural and divergent claims that different religions make. A theological system that shies away from the right to exercise a critique of religion on the basis of rationally and publicly demonstrable principles - such as the principle of "finite freedom," for example - must recognize as a legitimate religion even a form of religion that is nothing more than a project of power. And if, in fact, systemic corruption makes the constitution of autopoietic systems difficult - if not utterly impossible right from the outset! -, assuming the use of the religious contents as the normative criterion of religion would result in a futile exercise that not even the legal system and the "symbolic constitutional rights" 54 of peripheral modern societies could help to regulate - even minimally. After all, even the legal-police apparatus of the state is also, in our context, invaded by the economic interests of an extremely "petite élite financière" that has enough power to privatize any and all public institutions according to their own interests. ${ }^{55}$

7. Given that religious communication finds its norm in its religious use, as you stated in your lecture, how are we supposed to deal with a religious communication that claims to be in touch with that which is ultimately true? Would it not be appropriate to think that anyone who makes an honest appeal to the truth - of which it is only possible to have intuitions and rather provisory concepts -, and claims to have been approached by that which is ultimately and unconditionally true, also at the same time makes use of this unfathomable experience as the ultimate normative-regulative criterion in religious matters? I am raising this question because, as we are aware, the particularly new element presented by the science of religion as an academic discipline in its distinction

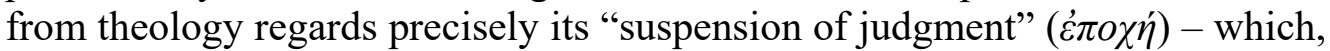
in any case, is not possible - in relation to the truth content of the religious traditions. Questions concerning the truth or untruth of religious substantive contents, the compatibility of religious piety with morality or the norms of life in society were decidedly left out by this academic discipline. ${ }^{56}$ For that reason,

\footnotetext{
${ }^{54}$ Cf. NEVES, M. A constitucionalização simbólica. São Paulo: Editora Acadêmica, 1994.

55 Cf. SOUZA, J. Die Naturalisierung der Ungleichheit. Ein neues Paradigma zum Verständnis peripherer Gesellschaften. Wiesbaden: VS Verlag für Sozialwissenschaften, 2008, above all, p. 143-179; SOUZA, J. A elite do atraso: da escravidão à Lava Jato. Rio de Janeiro: Leya, 2017.

${ }^{56}$ Cf. RUDOLPH, K. Die Religionswissenschaft zwischen Ideologie- und Religionskritik. In: KLINKHAMMER, G.; TOBIAS, F.; RINK, S. (Hg.). Kritik an Religionen. Religionswissenschaft und der kritische Umgang mit Religionen. Marburg: Diagonal, 1997, p. 67-76; MCCUTCHEON, R. T. Critics not Caretakers: The Scholar of Religion as Public
} 
Religion as a Self-Referential System of Religious Communication: An Assessment with Questions for a Challenging New Theological System

it was precisely in the suspension of judgment that the specifically new and peculiar element of the science of religion was found, even though its emergence was intertwined, in cultural-historical terms, with the discovery of the history of religion and with the religious-philosophical debates about the possible validating reasons (mögliche Geltungsgründe) of religious consciousness. ${ }^{57}$ These debates concerned, at the same time, the substance of Christianity in relation to other religions, the reciprocal influences between religion and culture, and the possibilities of an adequate categorial framework for probing religious phenomena. ${ }^{58}$ Now, if theology abandons the task of offering an adequate treatment of the validating reasons of religious consciousness, would it not be at the same time assuming a role - and restricting itself to it - that the science of religion claims for itself? In other words, are we truly able to avoid the truth claims of Christian religion, which, as such, must be reflexively true not only for Christians, but for the totality of humanity, without renouncing, at the same time, the peculiarity of the theological reflection? On the other hand, given the primacy of religious communication both for Christian religion and Christian theology, what use should we make of concepts so dear to the Christian faith such as "experience" and "conversion"? After all, does it not belong to Christian religion - and others! - the right to assert that a non-religious mode of self-interpretation is always and necessarily a self-interpretation that has not yet become transparent in relation to its unconditional dimension and, therefore, is in need of redemption? In other words, is the call to conversion that shapes (almost) every system of religious communication a constitutive part of this very system, or is it not?

8. The question I would like to raise in the following regards a criticism that you directed at Tillich, and which I cannot understand as a criticism that, in fact, does justice to the religious sensibility so characteristic of this author. In your lecture you stated that an autonomous self-interpretation seems to be always inferior when compared to a religious symbolic self-interpretation.

Intellectual. In: JENSEN, T; ROTHSTEIN, M. (Hg.). Secular Theories on Religion. Current Perspectives. Kopenhagen: Museum Tusculanum Press, 2000, p. 167-181; FIGL, J. Einleitung. Religionswissenschaft - Historische Aspekte, heutiges Fachverständnis und Religionsbegriff. In: FIGL, J. (Hg.). Handbuch Religionswissenschaft. Religionen und ihre zentralen Themen. Innsbruck; Wien: Tyrolia-Verlag; Göttingen: Vandenhoeck \& Ruprecht, 2003, p. 18-80. According to Figl, there is broad consensus in the emerging science of religion that it, the science of religion, is not normative; in contrast, "the philosophy of religion (like theology) is a normative science, while the science of religion represents an empirical point of view" (p. 38). Against the defense of "neutrality" in the academic study of religion, cf. SCHLIETER, J. Religion, Religionswissenschaft und Normativität, above all, p. 234-238.

57 Cf., for instance, KIPPENBERG, H. G.; STUCKRAD, K. v. Einführung in die Religionswissenschaft. Gegenstände und Begriffe. München: C. H. Beck, 2003, p. 24-36.

${ }^{58}$ The considerations elaborated above are in agreement with the text by Jörg Dierken. In this regard, cf. DIERKEN, J. Theologie, Religionswissenschaft und Religionsphilosophie: Grenzen und Übergänge. In: Ganzheit und Kontrafaktizität: Religion in der Sphäre des Sozialen. Tübingen: J. C. B. Mohr (Paul Siebeck), 2014, p. 55-78, here, p. 56. 
However, has Tillich not seen the possibility of an "unconscious religious cultural consciousness" 59 as well - which, as such, is also in need of redemption? By unconscious religious cultural consciousness, I mean that he can identify true religious motifs, especially in politics and art, for example, and see them as authentic religious expressions. If so, would that not mean that an autonomous self-description is not necessarily worse than, or inferior to, a religious self-description? Any protest against form, insofar as it denies form and points to something else, has both a demonic and a divine dimension. ${ }^{60}$ No matter which text I read by Tillich, I can never understand him as a theologian who claims to be a religious consciousness superior to a cultural one. On the contrary, insofar as all spheres of culture are based on the unconditioned, Tillich seems to me to be much more sensitive and inclined to see, precisely in the autonomy of culture, true religious drives, even if unconscious, than to promptly close them down as deficient self-descriptions and interpretations. The unconditional dimension of reality breaks through as a light in the midst of consciousness and, in the face of the living experience of unconditionality (Unbedingtheitserlebnis), ${ }^{61}$ every human being is, in principle, indefensible. In the same way, Tillich's theory of religion is capable of looking at the content of religious objectifications as a problem to be overcome precisely by denying its necessary concrete determinations. Thus, there is no self-consciousness which is not at the same time supported and criticized by the unconditioned, in such a way that true religion is lost the moment it is affirmed. The opposite also applies, namely, insofar as the concrete determinations of religious objectifications, i.e., of cultural forms, are denied, the paradoxical religion of the concrete spirit ${ }^{62}$ is

\footnotetext{
${ }^{59}$ Cf. TILLICH, P. Die Überwindung des Religionsbegriffs in der Religionsphilosophie. (1922). In: CLAYTON, J. P. (Hg.). Main Works - Hauptwerke. Band 4: Religionsphilosophische Schriften. Berlin; New York: Walter de Gruyter; Evangelisches Verlagswerk, 1987, p. 73-90, here, p. 81-82: „Es besteht nun für das Ich die Möglichkeit, seine Selbstgewißheit so zu erleben, daß die unbedingte Realitätsbeziehung, die darin enthalten ist, im Vordergrund steht; die a priori religiöse Art der Selbsterfassung; es besteht andererseits die Möglichkeit, seine Selbstgewißheit so zu erleben, daß die Beziehung auf das Sein des Ich im Vordergrund steht, die a priori unreligiöse Art der Selbsterfassung [...] Ob der Geist die religiöse oder unreligiöse Intention in sich trägt, ist theoretisch indifferent, da das Unbedingte zwar das Tragende auch alles theoretischen Urteils ist, selbst als absolute Voraussetzung aber niemals Gegenstand der Theorie sein kann".

${ }^{60}$ Cf. DANZ, C. Das Göttliche und das Dämonische. Paul Tillichs Deutung von Geschichte und Kultur. In: DANZ, C.; DUMAS, M.; SCHÜßLER, W.; STENGER, M. A.; STURM, E. (Hg.). Internationales Jahrbuch für die Tillich-Forschung. Band 8: Interpretation of History. Berlin; Boston: Walter de Gruyter GmbH, 2013, p. 1-14.

${ }^{61}$ Cf. TILLICH, P. Religionsphilosophie. (Sommersemester 1920). In: STURM, E. (Hg.). Ergänzungs- und Nachlaßbände zu den Gesammelten Werken von Paul Tillich. Band XII: Berliner Vorlesungen I (1919-1920). Berlin; New York: Walter de Gruyter GmbH \& Co. KG, 2001, for instance, p. 405.

${ }^{62}$ TILLICH, P. The Significance of the History of Religions for the Systematic Theologian. In: HUMMEL, G. (Hg.). Main Works - Hauptwerke. Band 6: Theologische Schriften. Berlin; New York: Walter de Gruyter; Evangelisches Verlagswerk, 1992, p. 431-446, here, p. 437.
} 
Religion as a Self-Referential System of Religious Communication: An Assessment with Questions for a Challenging New Theological System

disclosed to individual self-consciousness. Precisely because of this antinomic construction of the concept of religion, Tillich seems to me to insert a dynamic of affirmation and negation both in the autonomy of cultural consciousness and in the theonomy of religious consciousness. In other words, both are under the judgment of the unconditioned and remain irrevocably paradoxical. It is also in this direction that I read the dialogue between Tillich and his son René, in which he, again based on the paradoxical reformulation of the doctrine of justification by faith, states that the one who doubts the most is the most religious. As René Tillich writes in retrospect: "His ability to subsume people intellectually is well known. So, when I protested that I was an atheist he told me that I had the most faith because it is those who question the most who have the most faith. One obviously couldn't win." 63

9. Last but not least, how is it possible to assert that religion is at the same time a product of cultural evolution and an underivable event (unableitbares Ereignis)? If religion is a product of the cultural-evolutionary process, then the question for its genesis is either already indicated or consciously avoided. In any case, it would be difficult to assert, at the same time, however, that religion is also an underivable phenomenon without incurring in the risk of claiming a petitio principii.

In conclusion, I am almost sure I am not doing your system justice, Prof. Danz. My observations are, as mentioned earlier, merely preliminary and intuitive remarks, and not properly conceptual ones. My suspicious observations say much more about the place and standpoint from where I read your new system than about the fundamental and structuring contours of your systematic theology. In other words, my remarks do not constitute a careful, probing reading of a theological system that, in itself and by its own merit, demands rigorous attention. However, from these preliminary observations, one thing is certain: the place of your theological system in the history of twenty-first century Protestant theology is already assured. To scholars of Protestant theology - but not only! -, it is worth pursuing an intellectually honest and careful reading that takes into account not only the criticisms that your theological system imposes on the modern Protestant theological tradition, but also the fundamental contours that demarcate the distinctive and original character of your systematic theology. The autonomy and density of your encyclopedic knowledge and theoretical reflection, allied to the systematicity of your theological thinking, already provide more than enough reasons for our readers to feel not only invited but also encouraged to read your Pneumatologie and analyze your construction of a theory of religion under the systemictheoretical key of a system of religious communication. And here I cannot fail to register my gratitude for your desire and readiness to put your system under

${ }^{63}$ TILLICH, R. My Father, Paul Tillich. In: NORD, I.; SPIEGEL, Y. (Hg.). Spurensuche: Lebens- und Denkwege Paul Tillichs. Tillich-Studien. Band 5. Münster; Hamburg; London: LIT Verlag, 2001, p. 16. 
open and honest discussion in our still fragile Brazilian intellectual context. And even if one were to disagree with the perspective you advanced in your lecture, one would do well to remember that arguably your system has the undeniable merit of developing the insight that "security of knowledge does not lie in the exclusion of other possibilities of being, but in the ordering of the relationship between a being and its other possibilities." ${ }^{64}$ However, as usually is the case with Luhmann, it is easier said than done.

\section{References}

ABREU, Fábio Henrique. Símbolo como linguagem da religião: fundamentos da teoria dos símbolos no âmbito da teoria da religião de Paul Tillich. In: TADA, Elton Sadao; SOUZA, Vitor Chaves. (Org.). Paul Tillich e a linguagem da religião. Homenagem ao Prof. Dr. Etienne Alfred Higuet. Santo André: Kapenke, 2018, p. 365-582.

ADORNO, Theodor W. Aspekte. In: TIEDEMANN, Rolf. (Hg). Gesammelte Schriften. Band 5: Zur Metakritik der Erkenntnistheorie. Drei Studien zu Hegel. Frankfurt am Main: Suhrkamp Verlag, 1990, p. 251-294.

BARTH, Ulrich. Religion in der europäischen Aufklärung. In: BARTH, Ulrich; DANZ, Christian; GRÄB, Wilhelm; GRAF, Friedrich Wilhelm. (Hg.) Aufgeklärte Religion und ihre Probleme. Schleiermacher - Troeltsch Tillich. Berlin; Boston: Walter de Gruyter GmbH, 2013, p. 91-112.

BERGER, Peter L. The Sacred Canopy: Elements of a Sociological Theory of Religion. New York: Anchor Books, 1990.

; LUCKMANN, Thomas. Modernity, Pluralism and the Crisis of Meaning: The Orientation of Modern Man. Gütersloh: Bertelsmann Foundation Publishers, 1995.

CORDEMANN, Claas. Religion und Kultur. Paul Tillichs religionsphilosophische Grundlegung einer Theologie der Kultur. In: DANZ, Christian; SCHÜßLER, Werner. (Hg.). Paul Tillichs Theologie der Kultur:

\footnotetext{
${ }^{64}$ LUHMANN, N. Wahrheit und Ideologie. Vorschläge zur Wiederaufnahme der Diskussion. In: Soziologische Aufklärung. Band 1: Aufsätze zur Theorie sozialer Systeme. Opladen: Westdeutscher Verlag GmbH, 1991, p. 56: „Identität ist nicht Substanz, sondern eine koordinierende Synthese, die Verweisungen auf andere Erlebnismöglichkeiten ordnet. Und die Sicherheit des Wissens liegt nicht im Ausschluß anderer Seinsmöglichkeiten, sondern in der Ordnung des Verhältnisses eines Seienden zu seinen anderen Möglichkeiten“.
} 
Aspekte, Probleme, Perspektiven. Berlin; Boston: Walter de Gruyter GmbH \& Co. KG, 2011, p. 94-127.

DANZ, Christian. Vera et falsa religio. Zum Verhältnis von Religions- und Geltungstheorie in der Religionstheologie. In: DANZ, Christian; HERMANNI, Friedrich. (Hg.). Wahrheitsansprüche der Weltreligionen. Konturen gegenwärtiger Religionstheologie. Neukirchen-Vluyn: Neukirchener Verlagsgesellschaft, 2006, p. 191-210.

. Jesus Christus als Mitte der Geschichte. Die geschichtsphilosophischen Grundlagen von Paul Tillichs Christologie. In: HAIGIS, Peter; HUMMEL, Gert; LAX, Doris. (Hg.). Christus Jesus - „Mitte der Geschichte“!? Beiträge des X. Internationalen Paul-Tillich-Symposions Frankfurt/Main 2004. Berlin: LIT Verlag, 2007, p. 142-154.

. Das Göttliche und das Dämonische. Paul Tillichs Deutung von Geschichte und Kultur. In: DANZ, Christian; DUMAS, Marc; SCHÜßLER, Werner; STENGER, Mary Ann; STURM, Erdmann. (Hg.). Internationales Jahrbuch für die Tillich-Forschung. Band 8: Interpretation of History. Berlin; Boston: Walter de Gruyter GmbH, 2013, p. 1-14.

. Christianity and the Encounter of World Religions. Considerations to a Contemporary Theology of Religions. Revista Eletrônica Correlatio, vol. 15, no. 2, p. 9-26, 2016.

Gottes Geist. Eine Pneumatologie. Tübingen: Mohr Siebeck, 2019.

. Was ist Religion? Anmerkungen zu ihrem Verständnis. In: SCHREIBER, Gerhard. (Hg.). Interesse am Anderen: Interdisziplinäre Beiträge zum Verhältnis von Religion und Rationalität. Für Heiko Schulz zum 60. Geburtstag. Berlin; Boston: Walter de Gruyter GmbH, 2020, p. 3-17.

Theologie und Religion. Überlegungen $\mathrm{zu}$ einer umstrittenen Unterscheidung. In: HEIL, Uta; SCHELLENBERG, Annette. (Hg.). Theologie als Streitkultur. Wiener Jahrbuch für Theologie. Band 13. Göttingen: Vandenhoeck \& Ruprecht Verlag; University of Vienna Press, 2021, p. 139154.

DIERKEN, Jörg. Theologie, Religionswissenschaft und Religionsphilosophie: Grenzen und Übergänge. In: Ganzheit und Kontrafaktizität: Religion in der Sphäre des Sozialen. Tübingen: J. C. B. Mohr (Paul Siebeck), 2014, p. 55-78. 
EDER, Klaus. Europäische Säkularisierung - ein Sonderweg in die postsäkulare Gesellschaft? Berliner Journal Für Soziologie, 12, p. 295-307, 2002.

FIGL, Johann. Einleitung. Religionswissenschaft - Historische Aspekte, heutiges Fachverständnis und Religionsbegriff. In: FIGL, Johann. (Hg.). Handbuch Religionswissenschaft. Religionen und ihre zentralen Themen. Innsbruck; Wien: Tyrolia-Verlag; Göttingen: Vandenhoeck \& Ruprecht, 2003, p. $18-80$.

FREIBERGER, Oliver. Ist Wertung Theologie? Beobachtungen zur Unterscheidung von Religionswissenschaft und Theologie. In: LÖHR, Gebhard. (Hg.). Die Identität der Religionswissenschaft: Beiträge zum Verständnis einer unbekannten Disziplin. Frankfurt am Main: Peter Lang, 2000, p. 97-121.

GRÄB, Wilhelm. Resignieren Philosophie und Theologie angesichts des Pluralismus der Vernunftmodelle? Ein philosophisch-theologisches Plädoyer für eine vernünftige Religion der Menschenrechte. In: DANANI, Carla; PERONE, Ugo; RICHTER, Silvia. (Hg.). Die Irritation der Religion. Zum Spannungsverhältnis von Philosophie und Theologie. Göttingen: Vandenhoeck \& Ruprecht, 2016, p. 123-134.

GRAF, Friedrich Wilhelm. Die Wiederkehr der Götter: Religion in der modernen Kutur. München: Verlag C. H. Beck, 2004.

. Der eine Gott in vielerlei Gestalt. Die konfliktreiche Pluralisierungsdynamik in den drei monotheistischen Religionen. In: GALL, Lothar; DIETMAR, Willoweit. (Hg.). Judaism, Christianity, and Islam in the Course of History: Exchange and Conflicts. München: R. Oldenbourg Verlag, 2011, p. 1-17.

HÖLDERLIN, Friedrich. Patmos. (1803). In: SCHWAB, Christoph Theodor. (Hg.). Sämmtliche Werke. Zweiter Band: Nachlaß und Biographie. Stuttgart; Tübingen: J. G. Cotta'scher Verlag, 1846, p. 222-228.

HORNIG, Gottfried. Johann Salomo Semler. Studien zu Leben und Werk des Hallenser Aufklärungstheologen. Tübingen: Max Niemeyer Verlag GmbH \& Co. KG, 1996.

KANT, Immanuel. Prolegomena zu einer jeden künftigen Metaphysik, die als Wissenschaft wird auftreten können. In: WEISCHEDEL, Wilhelm. (Hg.). Immanuel Kant. Werke in zehn Bänden. Sonderausgabe. Band 5: Schriften zur Metaphysik und Logik. Darmstadt: Wissenschaftliche Buchgesellschaft, 1983, p. 109-264. 
Religion as a Self-Referential System of Religious Communication: An Assessment with Questions for a Challenging New Theological System

. Die Religion innerhalb der Grenzen der bloßen Vernunft. In: WEISCHEDEL, Wilhelm. (Hg.). Immanuel Kant. Werke in zehn Bänden. Sonderausgabe. Band 7: Schriften zur Ethik und Religionsphilosophie. Zweiter Teil. Darmstadt: Wissenschaftliche Buchgesellschaft, 1983, p. 645-879.

KIPPENBERG, Hans G.; STUCKRAD, Kocku von. Einführung in die Religionswissenschaft. Gegenstände und Begriffe. München: C. H. Beck, 2003.

KNOBLAUCH, Hubert. Ganzheitliche Bewegungen, Transzendenzerfahrung und die Entdifferenzierung von Kultur und Religion in Europa. Berliner Journal Für Soziologie, 12, p. 295-307, 2002.

KRECH, Volkhard. Wissenschaft und Religion: Studien zur Geschichte der Religionsforschung in Deutschland 1871 bis 1933. Tübingen: J. C. B. Mohr (Paul Siebeck), 2002.

LATOUR, Bruno. Nous n'avons jamais été modernes. Essai d'anthropologie symétrique. Paris: Éditions La Découverte \& Syros, 1997.

LAUSTER, Jörg. Liberale Theologie: Eine Ermunterung. Neue Zeitschrift für Systematische Theologie und Religionsphilosophie, 49, 3, p. 291-307, 2008.

LEHMANN, Hartmut. Von der Erforschung der Säkularisierung zur Erforschung von Prozessen der Dechristianisierung und der Rechristianisierung im neuzeitlichen Europa. In: LEHMANN, Hartmut. (Hg.): Säkularisierung, Dechristianisierung, Rechristianisierung im neuzeitlichen Europa. Bilanz und Perspektiven der Forschung. Göttingen: Vandenhoeck \& Ruprecht, 1997, p. 9-16.

LÖWITH, Karl. «Der okkasionelle Dezisionismus von C. Schmitt». (1935). In: Sämtliche Schriften. Band 8: Heidegger - Denker in dürftiger Zeit. Zur Stellung der Philosophie im 20. Jahrhundert. Stuttgart: J. B. Metzler'sche Verlagsbuchhandlun), 1984, p. 32-71.

LUHMANN, Niklas. Die Weltgesellschaft. Archiv für Rechts- und Sozialphilosophie/Archives for Philosophy of Law and Social Philosophy, 1971, vol. 57, no. 1, p. 1-35, 1971.

LUHMANN, Niklas. Die Ausdifferenzierung der Religion. In: Gesellschaftsstruktur und Semantik. Studien zur Wissenssoziologie der 
modernen Gesellschaft. Band 3. Frankfurt am Main: Surhkamp Verlag, 1989, p. 259-357.

. Political Theory in the Welfare State. Berlin; New York: Walter de Gruyter \& Co, 1990, p. 34-39.

. Wahrheit und Ideologie. Vorschläge zur Wiederaufnahme der Diskussion. In: Soziologische Aufklärung. Band 1: Aufsätze zur Theorie sozialer Systeme. Opladen: Westdeutscher Verlag GmbH, 1991, p. 54-65.

. Zur Einführung. In: NEVES, Marcelo. Verfassung und Positivität des Rechts in der peripheren Moderne: Eine theoretische Betrachtung und eine Interpretation des Falls Brasilien. Berlin: Duncker und Humblot, 1992, p. 1-4.

. Inklusion und Exklusion. In: Soziologische Aufklärung. Band 6: Die

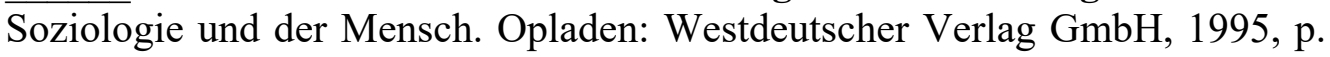
237-264.

MCCUTCHEON, Russell T. Critics not Caretakers: The Scholar of Religion as Public Intellectual. In: JENSEN, Tim; ROTHSTEIN, Mikael. (Hg.). Secular Theories on Religion. Current Perspectives. Kopenhagen: Museum Tusculanum Press, 2000, p. 167-181.

MEDEIROS, Martha. A morte devagar. In: Non-Stop. Crônicas do cotidiano. Porto Alegre: L\&PM Editores, 2001, p. 145.

MOLTMANN, Jürgen. Gott in der Schöpfung. Ökologische Schöpfungslehre. München: Chr. Kaiser Verlag, 1985.

NEVES, Marcelo. Verfassung und Positivität des Rechts in der peripheren Moderne: Eine theoretische Betrachtung und eine Interpretation des Falls Brasilien. Berlin: Duncker und Humblot, 1992.

1994.

A constitucionalização simbólica. São Paulo: Editora Acadêmica,

POLLACK, Detlef. Säkularisierung - ein moderner Mythos? Studien zum religiösen Wandel in Deutschland. Tübingen: J. C. B. Mohr (Paul Siebeck), 2003.

ROYAL, Zachary. Cultural Transformation as Ultimate Concern: Tillich in Conversation with the Black Liberation Theology of James Cone. In: BANDY, 
Religion as a Self-Referential System of Religious Communication: An Assessment with Questions for a Challenging New Theological System

Thomas G. (Ed.). Why Tillich? Why Now? Macon: Mercer University Press, 2021, p. 265-275.

RUDOLPH, Kurt. Die Religionswissenschaft zwischen Ideologie- und Religionskritik. In: KLINKHAMMER, Grint; TOBIAS, Frick; RINK, Steffen. (Hg.). Kritik an Religionen. Religionswissenschaft und der kritische Umgang mit Religionen. Marburg: Diagonal, 1997, p. 67-76.

RUNG, Daile Lynn. Processes of Sub-Citizenship: Neoliberal Statecrafting 'Citizens,' 'Non-Citizens,' and Detainable 'Others'. Social Sciences, no. 1:5, vol. 9, p. 1-30, 2000.

SCHLIETER, Jens. Religion, Religionswissenschaft und Normativität. In: STAUSBERG, Michael. (Hg.). Religionswissenschaft. Berlin; Boston: Walter de Gruyter GmbH \& Co. KG, 2012, p. 227-240.

SCHMITT, Carl. Politische Romantik. Sechste Auflage. Berlin: Duncker und Humblot, 1998.

SCHÜTTE, Hans-Walter. Religionskritik und Religionsbegründung. In: SCHIFFERS, Norbert; SCHÜTTE, Hans-Walter. (Hg.). Zur Theorie der Religion. Freiburg; Basel; Wien: Herder Verlarg, 1973, p. 95-135.

SIMMEL, Georg. Zur Soziologie der Religion. Neue Deutsche Rundschau (Freie Bühne), 9, p. 11-123, 1898.

. Die Religion. Frankfurt am Main: Literarische Anstalt Rütten \& Loening, 1906.

SOUZA, Jessé. Die Naturalisierung der Ungleichheit. Ein neues Paradigma zum Verständnis peripherer Gesellschaften. Wiesbaden: VS Verlag für Sozialwissenschaften, 2008. 2017.

A elite do atraso: da escravidão à Lava Jato. Rio de Janeiro: Leya,

STRAUSS, David Friedrich. Die christliche Glaubenslehre in ihrer geschichtlichen Entwicklung und im Kampfe mit der modernen Wissenschaft dargestellt. Zweiter Band. Tübingen: C. F. Osiander; Stuttgart: F. H. Köhler, 1841.

STRAUSS, Leo. Anmerkungen zu Carl Schmitt, Der Begriff des Politischen. In: MEIER, Heinrich. (Hg.). Carl Schmitt, Leo Strauss und »Der Begriff des 
Politischen «. Zu einem Dialog unter Abwesenden. Dritte Auflate. Stuttgart; Weimar: J. B. Metzler'sche Verlagsbuchhandlung; Carl Ernst Poeschel Verlag GmbH, 2013, p. 99-125.

TAYLOR, Charles. Sources of the Self: Making of the Modern Identity. Cambridge: Harvard University Press, 1989.

TILLICH, Paul. Systematic Theology. Vol. I: Reason and Revelation, Being and God. Chicago: The University of Chicago Press, 1951.

. Die Theologie des Kairos und die gegenwärtige geistige Lage. Offener Brief an Emanuel Hirsch von Paul Tillich. In: ALBRECHT, Renate; TAUTMANN, René. (Hg.). Ergänzungs- und Nachlaßbände zu den Gesammelten Werken von Paul Tillich. Band VI: Briefwechsel und Streitschriften. Theologische, philosophische und politische Stellungnahmen und Gespräche. Frankfurt am Main: Evangelisches Verlagswerk, 1983, p. 142176.

. Die Überwindung des Religionsbegriffs in der Religionsphilosophie. (1922). In: CLAYTON, John Powell. (Hg.). Main Works - Hauptwerke. Band 4: Religionsphilosophische Schriften. Berlin; New York: Walter de Gruyter; Evangelisches Verlagswerk, 1987, p. 73-90.

. Religionsphilosophie. (1925). In: CLAYTON, John Powell. (Hg.). Main Works - Hauptwerke. Band 4: Religionsphilosophische Schriften. Berlin; New York: Walter de Gruyter; Evangelisches Verlagswerk, 1987, p. 117-170.

. Cristologie und Geschichtsdeutung. (1930). In: HUMMEL, Gert. (Hg.). Main Works - Hauptwerke. Band 6: Theologische Schriften. Berlin; New York: Walter de Gruyter; Evangelisches Verlagswerk, 1992, p. 127-149.

. The Significance of the History of Religions for the Systematic Theologian. In: HUMMEL, Gert. (Hg.). Main Works - Hauptwerke. Band 6: Theologische Schriften. Berlin; New York: Walter de Gruyter; Evangelisches Verlagswerk, 1992, p. 431-446.

. Systematische Theologie von 1913. In: HUMMEL, Gert; LAX, Doris. (Hg.). Ergänzungs- und Nachlaßbände zu den Gesammelten Werken von Paul Tillich. Band IX: Frühe Werke. Berlin; New York: Walter de Gruyter GmbH \& Co. KG, 1998, p. 273-434. 
Religion as a Self-Referential System of Religious Communication: An Assessment with Questions for a Challenging New Theological System

. Religionsphilosophie. (Sommersemester 1920). In: STURM, Erdmann. (Hg.). Ergänzungs- und Nachlaßbände zu den Gesammelten Werken von Paul Tillich. Band XII: Berliner Vorlesungen I (1919-1920). Berlin; New York: Walter de Gruyter GmbH \& Co. KG, 2001, p. 333-584.

. Dogmatik-Vorlesung. (Dresden 1925-1927). In: SCHÜßLER, Werner; STURM, Erdmann. (Hg.). Ergänzungs- und Nachlaßbände zu den Gesammelten Werken von Paul Tillich. Band XIV. Berlin; New York: Walter de Gruyter GmbH \& Co., KG, 2005, p. 1-440.

TILLICH, René. My Father, Paul Tillich. In: NORD, Ilona; SPIEGEL, Yorick. (Hg.). Spurensuche: Lebens- und Denkwege Paul Tillichs. Tillich-Studien. Band 5. Münster; Hamburg; London: LIT Verlag, 2001, p. 9-22.

TROELTSCH, Ersnt. Was heißt „Wesen des Christentums“?. In: Gesammelte Schriften. Zweiter Band: Zur religiösen Lage, Religionsphilosophie und Ethik. Tübingen: Verlag von J. C. B. Mohr (Paul Siebeck), p. 386-451.

. Wesen der Religion und der Religionswissenschaft. In: Gesammelte Schriften. Zweiter Band: Zur religiösen Lage, Religionsphilosophie und Ethik. Tübingen: Verlag von J. C. B. Mohr (Paul Siebeck), p. 452-499.

WAGNER, Falk. Was is Religion? Studien zu ihrem Begriff und Thema in Geschichte und Gegenwart. Gütersloh: Gütersloher Verlagshaus Gerd Mohn, 1986.

. Kann die Religion der Moderne die Moderne der Religion ertragen? Religionssoziologische und theologisch-philosophische Erwägungen im Anschlus an Niklas Luhmann. In: DANZ, Christian; DIERKEN, Jörg; MURRMANN-KAHL, Michael. (Hg.). Religion zwischen Rechtfertigung und Kritik. Perspektiven philosophischer Theologie. Frankfurt am Main: Peter Lang GmbH; Internationaler Verlag der Wissenschaften, 2005, p. 173-201.

WEBER, Max. Die Objektivität sozialwissenschaftlicher und sozialpolitischer Erkenntnis. (1904). In: Gesammelte Aufsätze zur Wissenschatslehre. Tübingen: Verlag von J. C. B. Mohr (Paul Siebeck), 1922, p. 146-214.

Wissenschaft als Beruf. In: MOMMSEN, Wolfgang J.; SCHLUCHTER, Wolfgang. (Hg.). Max Weber Gesamtausgabe. Band 17. Abteilung I: Schriften und Reden. Tübingen: J. C. B. Mohr (Paul Siebeck), 1992, p. 49-112. 
. Die protestantische Ethik und der „Geist“" des Kapitalismus. Neuausgabe der ersten Fassung von 1904-05 mit einem Verzeichnis der wichtigsten Zusätze und Veränderungen aus der zweiten Fassung von 1920. Herausgegeben und eingeleitet von Klaus Lichtblau und Johannes Weiß. Wiesbaden: Springer VS, 2016.

WITTEKIND, Folkart. Karl Barth und die moderne Predigt: Homiletik und Glaubensverständnis bei Niebergall, Tillich und Karl Barth. Zeitschrift für Theologie und Kirche, vol. 98, no. 3, p. 344-371, 2001.

- Die Vernunft des Christusglaubens. $\mathrm{Zu}$ den philosophischen Hintergründen der Christologie der Marburger Dogmatik. In: DANZ, Christian; SCHÜßLER, Werner; STURM, Erdmann. (Hg.). Internationales Jahrbuch für die Tillich-Forschung. Band 1: Wie viel Vernunft braucht der Glaube? Wien: LIT Verlag, 2005, p. 133-157.

Submetido em: 24-1-2022

Aceito em: 25-1-2022 